Discussion

Papers

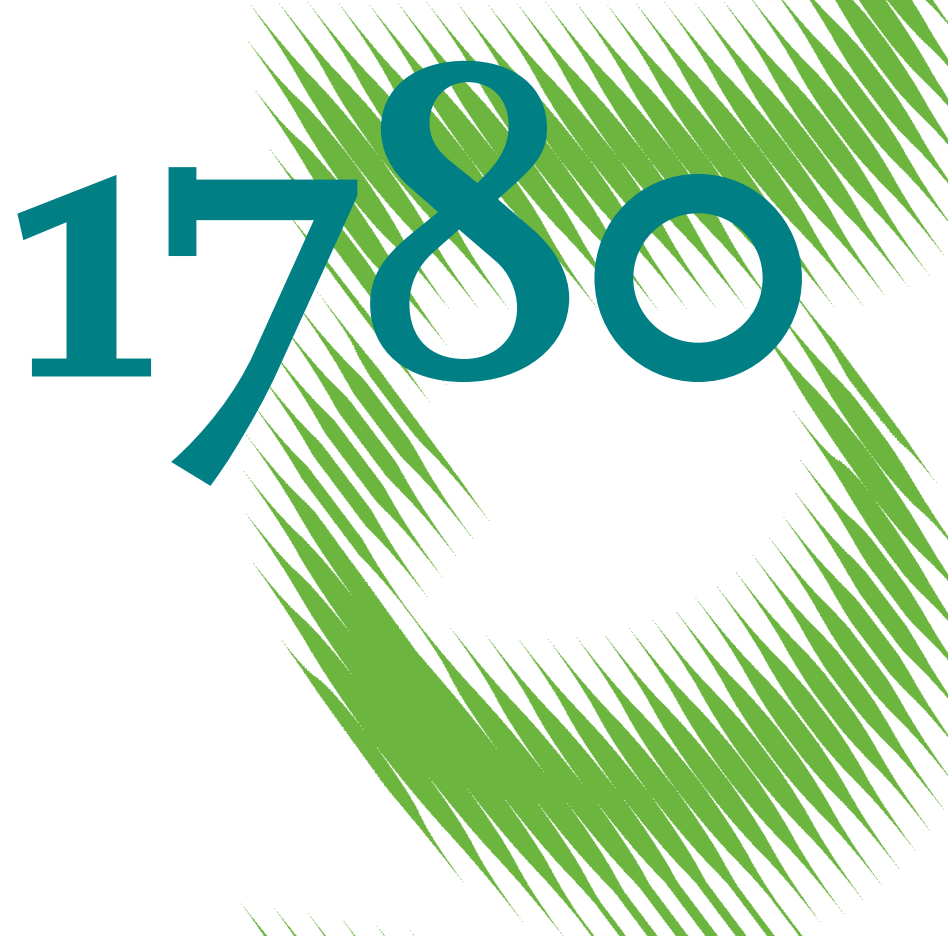

Housing Rent Dynamics and Rent Regulation in St. Petersburg (1880-1917) 
Opinions expressed in this paper are those of the author(s) and do not necessarily reflect views of the institute.

IMPRESSUM

(C) DIW Berlin, 2019

DIW Berlin

German Institute for Economic Research

Mohrenstr. 58

10117 Berlin

Tel. +49 (30) $89789-0$

Fax +49 (30) $89789-200$

http://www.diw.de

ISSN electronic edition 1619-4535

Papers can be downloaded free of charge from the DIW Berlin website:

http://www.diw.de/discussionpapers

Discussion Papers of DIW Berlin are indexed in RePEc and SSRN:

http://ideas.repec.org/s/diw/diwwpp.html

http://www.ssrn.com/link/DIW-Berlin-German-Inst-Econ-Res.html 


\title{
Housing Rent Dynamics and Rent Regulation in St. Petersburg (1880-1917)
}

\author{
Konstantin A. Kholodilin ${ }^{\mathrm{a}, \mathrm{b}}$, Leonid E. Limonov ${ }^{\mathrm{b}, \mathrm{c}}$, Sofie R. Waltl ${ }^{\mathrm{d}, \mathrm{e}}$ \\ ${ }^{a}$ DIW Berlin, Mohrenstraße 58, 10117, Berlin, Germany \\ ${ }^{b}$ NRU HSE, Kantemirovskaya ul., 3/1, 194100, St. Petersburg, Russia \\ ${ }^{c}$ Leontief Centre, 7-aya Krasnoarmeyskaya ul. 25, 190005, St. Petersburg, Russia \\ ${ }^{d}$ Luxembourg Institute of Socio-Economic Research, Maison des Sciences Humaines, 11, Porte des Sciences, 4366 \\ Esch-sur-Alzette/Belval, Luxembourg \\ ${ }^{e}$ Vienna University of Economics and Business, Welthandelsplatz 1, 1020 Vienna, Austria
}

\begin{abstract}
This article studies the evolution of housing rents in St. Petersburg between 1880 and 1917, covering an eventful period of Russian and world history. We collect and digitize over 5,000 rental advertisements from a local newspaper, which we use together with geo-coded addresses and detailed structural characteristics to construct a quality-adjusted rent price index in continuous time. We provide the first pre-war and pre-Soviet index based on market data for any Russian housing market. In 1915, one of the world's earliest rent control and tenant protection policies was introduced in response to soaring prices following the outbreak of World War I. We analyze the impact of this policy: while before the regulation rents were increasing at a similar rapid pace as other consumer prices, the policy reversed this trend. We find evidence for official compliance with the policy, document a rise in tenure duration and strongly increased rent affordability among workers after the introduction of the policy. We conclude that the immediate prelude to the October Revolution was indeed characterized by economic turmoil, but rent affordability and rising rents were no longer the dominating problems.
\end{abstract}

Keywords: Rental Market; Rent Regulation; Intra-Urban Rent Dynamics; Hedonic Rent Price Index; Economic History; Pre-Soviet Russia; October Revolution.

JEL classification: C14; C43; N93; O18.

Notes and Acknowledgments: We thank Arina Gromyko, Alyona Kamionko, Sergey Kozyrev, Darya Kryutchenko, Elizaveta Lekomtseva, Darya Parfyonova, Il'ya Sazankin, Ivan Sorokin, and Bogdan Sukhoterin for their kind help in collecting the data. We are thankful for comments by Kilian Rieder and Se Yan as well as by participants at the LISER Research Seminar, the WU Research Seminar in Economic, Social, and Business History, as well as the XVIII World Economic History Congress at MIT. Konstantin Kholodilin is the corresponding author: kkholodilin@diw.de. 


\section{Introduction}

Throughout history, "[w]ar, that prolific parent of legislation, has spawned more rent regulation than any other cause" (Willis, 1950, p. 54). While early forms of regulation date back to Ancient Rome (where Caesar capped the rents for Roman villas, see Willis, 1950, p. 59), World War I constitutes the triggering momentum for the large-scale adoption of rent control policies in modern times. The Russian Empire is no exception in this respect.

There, a large inflow of refugees in the summer of 1915 turned the lingering housing shortage into a full-fledged housing crisis. In such conditions, the rental housing market that previously knew virtually no restrictive regulations responded with a rapid rent increase, which exacerbated overall inflation. The local authorities attempted to counteract this development first by freezing rents and, shortly thereafter, by additionally prohibiting the arbitrary eviction of tenants.

All local policies were very similar in their design: in many cases, regional governments imitated the regulations adopted by other regions. Often, the intervention was justified by factual or putative speculative rent increases. For instance, the preamble of the compulsory ordinance of Dvinskiy military district as of August 9 (July 28), $1915^{1}$ justifies government intervention as follows: $^{2}$

In order to avoid the arbitrary increases of rents for apartments undertaken with the sole objective of realizing speculative profits and taking advantage of the wartime circumstances, it is prohibited $[\ldots]$ to raise the rents above the rental prices payable at the moment of issuing this Ordinance.

A similar paragraph introduces the compulsory ordinance issued by the commander of the fortress Alexandropol (today Gyumri in Armenia) on September 22 (9), 1915:3,4

In the view of artificial and selfish rent increases in Alexandropol that force the low-rank railway and other civil servants to either move to the worse dwellings located farther from the railway station or to leave the government service in Alexandropol, which I consider to be a threat to the public security, I hereby $[\ldots]$ prohibit to increase the rent $[\ldots]$ above the rental price payable at the date of entry in force of this Ordinance.

At the end of 1915, a restrictive rent control and tenant protection regulation was also adopted in St. Petersburg/Petrograd,${ }^{5}$ the capital of the Russian Empire and one of the largest cities in the world at

\footnotetext{
${ }^{1}$ Here and in what follows, we express dates using the today's usual Gregorian calendar. In parentheses, the date according to the Julian calendar is reported, which was used in Russia prior to 1918.

${ }^{2}$ Vilenskiye gubernskie vedomosti, August 1, 1915, no. 59.

${ }^{3}$ Izvestiya Erivanskogo gubernskogo komissariata (Gubernskie vedomosti), October 3, 1915, no. 77.

${ }^{4}$ Almost identical passages are part of the preambles in other regional compulsory ordinances, e.g., in those of Kaluga governorate on August 5 (July 23), 1915; Kavkazskiy kray on February 20 (7), 1916; and Kievskiy governorate on October $21(8), 1915$.

${ }^{5}$ Between 1914 and 1924 St. Petersburg was named Petrograd. Throughout the article we refer to the city as St. Petersburg to avoid confusion.
} 
that time. To our knowledge, nothing is known about the effectiveness and consequences of this policy. Was it able to end the housing crisis or did soaring rents lead up to the October Revolution? While it is well established that the prelude to the Revolution was characterized by problematic economic conditions particularly among the working class population, was rent affordability one of the major problems? In today's rental markets, the effects of new policies are confounded by existing regulations. Hence, how does a completely unregulated market react on such a policy?

In pre-Soviet St. Petersburg, the cost of housing is best understood by studying housing rents because the vast majority of city dwellers were indeed renters. During the period under inspection, the homeownership rate in St. Petersburg was low, fluctuating around 3.6\%. Thus, an analysis of the rental market is of predominant importance.

In order to address our research questions, we searched for newspaper rental advertisements, collecting from these the asking rent, the publishing date, the exact address, and a long list of structural characteristics. The newspapers are archived in the Russian National Library in St. Petersburg. We assemble a new data base by digitizing the information in the advertisements. Additionally, we geo-code the reported addresses taking into account changes in street names and the road network over time.

Using these data, we construct a rent index for St. Petersburg based on market data for the period between 1880 and 1917. We do not just provide the first market data based index for St. Petersburg, but for, in fact, any housing market in Tsarist Russia.

We apply a hedonic approach to construct quality-adjusted index numbers. We model time nonparametrically. This yields a time-continuous index (Waltl, 2016a) that is well suited in the presence of rather low numbers of observations per year and that allows us to study price dynamics following the introduction of the rent control policy in real time. In addition, we use state-of-the-art spatial econometric tools that take into account St. Petersburg's topographic particularities: known as the "Venice of the North," the city is characterized by waterways and rivers dividing up the urban area. A soap-film smoother (Wood et al., 2008) models this particular urban shape and captures locational variation in price levels in the hedonic model.

We benchmark the resulting index against standard hedonic time-dummy indices and a repeat-rent index. While all indices report very similar overall trends, the time-continuous index out-performs the other approaches in terms of stability and timeliness.

We find that housing rents were quite stable between 1880 and the early 1890s. This fundamentally changes from 1905 onward: the second part of our observation window covers an eventful period of Russian and world history, which is reflected by turbulence in the rental market. Never before seen upand down-swings characterize this period. A particularly strong rise in rents is observed following the outbreak of World War I. The rent control policies swamping the Russian Empire appear to be a reaction to such extraordinary increases, which is in line with Willis' (1950) conclusions on war being the major motivator for rent control policies. 
We perform an event study to assess the impact of the rent control policy on the overall rent level. Our results are unambiguous: the effective date of the ordinance constitutes a remarkable turning point in the rent index. Not only did rents stop from further increasing, rental prices in fact plunged and, within a year, returned to pre-war levels.

The policy also included a tenant protection component, which prohibited the eviction of tenants as long as they paid the rent. From address directories, we estimate an average tenure duration before and after 1915, and find a significant increase in tenure duration once the policy was put in place.

Moreover, we make use of repeatedly advertised rental units to analyze changes in landlords' behavior. While the rental market was unregulated, landlords frequently adjusted (asking) rents of the same dwelling, even over very short periods of time. After the issuance of the policy, we do not observe any price changes at all, which hints at strong official compliance with the regulation. However, anecdotal evidence suggests that landlords probably relied on indirect ways (e.g., key money) to compensate for foregone rental income.

We predict average rents in St. Petersburg's three workers' districts from the spatial hedonic model estimated in the course of the index construction. We compare these prices to wages earned by building laborers and carpenters (collected by Allen and Khaustova, 2018) and compute rent-to-wage ratios as a measure of affordability. Over the period under investigation, the rental burden on workers was generally large. We conclude that many workers had to share a room to afford the high rents, which is in-line with the high crowding rates documented in the housing censuses. After 1915, rent-to-wage ratios fell to never seen before low levels due to both, rising wages and falling rents. While other prices kept on increasing rapidly (by October 1917, historians even speak of hyperinflation), rents followed a different path and we conclude that rent affordability was not one of the prevailing problems in the two years preceding the Revolution. Instead, it became virtually impossible to find a vacant dwelling for such low rents.

Our findings contribute to a better understanding of the economic conditions of the shaking times preceding the 1917 October Revolution, which constitutes the end of capitalism in Russia. In this sense, we extend the work of Samy (2015), who compiles house price and rent indices for London covering the 1895 to 1939 period to study the so-called "housing problem." He points out that the cost of housing consumed large shares of working- and middle-class incomes before World War I and in the inter-war period, and concludes that the "housing problem" was a severe social and economic issue of that time.

For Russia, such an analysis is missing. However, we tie in with Allen and Khaustova's (2018) work, which collects prices (but not rents) and wages for three Russian cities (St. Petersburg, Moscow, and Kursk) and studies the evolution of real wages and living standards over four politically very distinct periods, the pre-war Imperial, the early Soviet, New Economic Policy, and the initial two Five Year Plans.

In addition to the economic and social history literature, we also contribute to current attempts to construct historic and long-term housing price and rent indices. Such series are important for studying long-term trends in the housing and rental market, the prevalence of housing cycles, the rate of return to 
real estate, the relationship of prices and rents over time, as well as to test hypotheses regarding long-run link to the general business cycle.

In his pioneering work, Eichholtz (1997) constructs a long-term price index for dwellings located in the Herengracht in Amsterdam for 1628 to 1973 period. Since then, much work has been done to explore historic data sources and construct long-term housing price indices for various cities, e.g., Eitrheim and Erlandsen (2004), several Norwegian cities 1819-2003; Ambrose et al. (2013), Amsterdam 1650-2005; Nicholas and Scherbina (2013), Manhattan 1920-1939; Raff et al. (2013), Beijing 1644-1840; Carmona et al. (2017), Spain 1904-1934; and Lyons (2018), Dublin 1900-2017. Knoll et al. (2017) present housing price indices for 14 developed economies for 1870 to 2012 period, thus substantially extending our knowledge about long-term housing market developments.

For the rental market, there are mainly time series focusing on (shorter or longer) periods in history: Margo (1996), New York 1830-1860; Clark (2002), England and Wales 1550-1909; Eichholtz et al. (2012), Amsterdam 1550-1850; Gray (2015), New York, 1880-1910; Samy (2015), London 1895-1939; and Kholodilin (2016), Berlin 1909-1917. Eichholtz et al. (2018) are, to our knowledge, the only ones constructing long-term series up until today. They study 500 years of urban rents, changes in housing quality, and housing affordability for several Belgian cities as well as Paris, London, and Amsterdam.

The rent control and tenant protection policies introduced during World War I in Russia were plain and radical. While, in the short term, the policy appears to have been effective in bringing down skyrocketing rents and relieving the financial burden on workers, we cannot draw any long-term conclusions: with the end of capitalism, the housing stock was nationalized, which constitutes the end of a rental market. Still, studying such a non-complex policy, targeting almost the universe of rental units and issued in a previously unregulated market provides a much cleaner estimate of short-term effects than the analysis of today's complex and nuanced policies that often come on top of a large body of existing rules, (a problem also pointed out by Sims, 2007). In this sense, we contribute some evidence to the heated debate on contemporaneous rent regulation (see for instance Arnott, 1995; Autor et al., 2014; Diamond et al., 2018; Kholodilin et al., 2018) and provide some general insights that may be helpful for policy-analysts and -makers.

The remainder of this article is organized as follows. First, section 2 presents the newly assembled data set. Thereafter, section 3 describes the compilation and results obtained from the principal hedonic rent index in continuous time as well as three benchmark indices. Then, section 4 describes the features of the rent control and tenant protection policy, and analyses its impact on the overall rent level, tenure duration, landlords' setting of asking prices, and changes in housing affordability for two types of workers - building laborers and carpenters. Finally, section 5 concludes. The article is accompanied by an appendix containing ample background information on demographics and the historic housing market in St. Petersburg, historic events that shaped the period of investigation, as well as technical details. In addition, a data appendix contains the full set of quantitative results. 


\section{Data}

\subsection{Real Estate Advertisements}

Kosinskaya (2016) describes four ways to find a place to rent in St. Petersburg's pre-revolutionary housing market. Fist, one could simply walk around and observe the windows of residential buildings. In the middle of the window, a landlord, who had vacant premises, would place a piece of paper and the color would indicate the type of rental unit available: dark blue indicated the vacancy of an entire apartment, white a room, and green a vacant part of a room or a corner. The second way was to consult classified advertising in a newspaper. ${ }^{6,7}$ The third option was to visit the Kopanygin real estate agency, which was located in the city center and had a catalog of rental dwellings, often accompanied by photographs. ${ }^{8}$ The last option was, like today, word of mouth.

\section{Table 1: Summary statistics}

\begin{tabular}{|c|c|c|c|c|}
\hline & Mean & 1st Quartile & Median & 3rd Quartile \\
\hline Weekly rent, rubles & 49.86 & 25.00 & 40.00 & 60.00 \\
\hline Number of rooms & 3.74 & 2.00 & 4.00 & 5.00 \\
\hline \multicolumn{5}{|l|}{ Share of } \\
\hline apartments vs. rooms & & & $88.37 \%$ & $11.63 \%$ \\
\hline bathroom vs. no bathroom & & & $22.87 \%$ & $77.13 \%$ \\
\hline heating vs. no heating & & & $33.61 \%$ & $66.39 \%$ \\
\hline electricity vs. no electricity & & & $7.01 \%$ & $92.99 \%$ \\
\hline furnished vs. unfurnished & & & $99.78 \%$ & $0.22 \%$ \\
\hline balcony vs. no balcony & & & $3.12 \%$ & $96.88 \%$ \\
\hline \multicolumn{3}{|c|}{ Total number of observations: } & \multicolumn{2}{|c|}{5,037} \\
\hline \multicolumn{3}{|c|}{ Average number of observations per year: } & \multicolumn{2}{|c|}{132.55} \\
\hline \multicolumn{3}{|c|}{ Min. and max. number of observations per year: } & \multicolumn{2}{|c|}{$[44 ; 331]$} \\
\hline \multicolumn{3}{|c|}{ Date of first observation: } & \multicolumn{2}{|c|}{ Jan $13(1), 1880$} \\
\hline \multicolumn{3}{|l|}{ Date of last observation: } & \multicolumn{2}{|c|}{ Nov 12 (Oct 29), 1917} \\
\hline
\end{tabular}

Notes: The table reports summary statistics for asking rents and characteristics of the advertised apartment or room collected from "Peterburgskaya gazeta."

In this article, we exclusively rely on newspaper advertisements, as this is the only readily available data source we can access today. The advertisements refer to either an entire apartment or a room in a shared apartment. We collect advertisements from the newspaper "Peterburgskaya gazeta" (after the entrance of Russia into World War I, it was renamed to "Petrogradskaya gazeta"), which was published between 1867 and November 1917, when it was closed by the Bolshevik government. Between 1878

\footnotetext{
${ }^{6}$ In most cases, the potential tenants went to the addresses reported in the advertisements. Rarely, they could also make a telephone call - only 75 advertisements out of more than 5,000 contain telephone numbers. Overall, the coverage of private telephones at that time was very modest: the number of telephone holders increased from 259 in 1882 , when telephonic communication was introduced in St. Petersburg, to 57,423 in 1917. Thus, at the end of the observation period, there were only 25 telephones per 1,000 inhabitants (see Avrukh, 2004).

${ }^{7}$ The literacy rate in St. Petersburg was high enough to assume that the vast majority of people could indeed rely on newspaper advertisements to find a place to live. See Appendix A, section Literacy for details.

${ }^{8}$ The agency published its own bulletin containing information about dwellings to let. Unfortunately, the archives of the agency could not be located. For more details on the activities of this agency see Kruzhnov (2014).
} 
and 1882, it appeared five times a week; in 1882 it became a daily newspaper. We looked at all other newspapers archived in the National Library, but "Peterburgskaya gazeta" is the one containing the largest section of rental advertisements. Thus, we are confident that our data source is comprehensive in describing newspaper-advertised rentals.

Nonetheless, we miss rental agreements that were established in an informal way or via the real estate agency. It is likely that we miss the very top and the very bottom of the market. The rental units the advertisements refer to are spread across the entire city, thus, a geographic selection bias is unlikely. Additionally, we compare our indices to a cost of rental accommodation index compiled by the Soviet economist V. L. Dalmatov (mainly based on decennial census data and documented in Strumilin, 1966). For the overlapping period, trends are very similar. Thus, we believe that our index is able to track overall changes in the rent level reasonably well. ${ }^{9}$

We did not rely on any sampling strategy but collected the entirety of rental advertisements: all rental advertisements published in any issue of the newspaper and containing a rental price were digitized. The announcements include detailed structural and locational characteristics. Summary statistics are reported in Table 1. As an example, Figure 1 shows such advertisements as they appear in the newspaper.

\section{Figure 1: Historic newspaper advertisements}

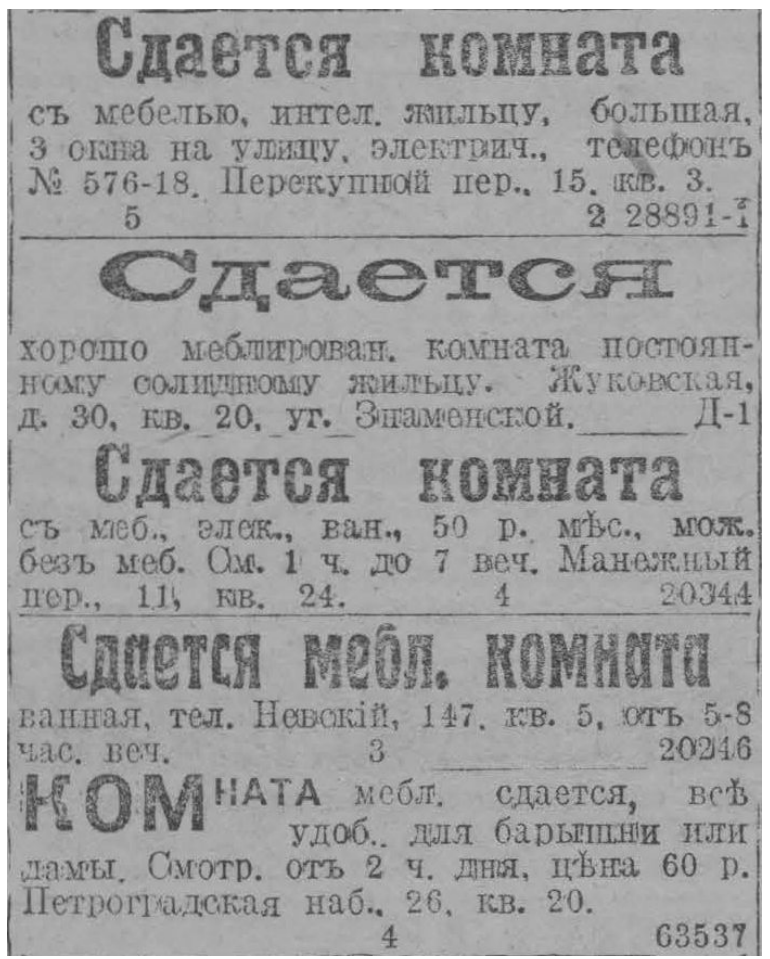

Notes: These advertisements appeared in the Petrogradskaia gazeta on September 26, 1917.

\footnotetext{
${ }^{9} \mathrm{An}$ index based on census data summarizes the price level of all existing rental contracts. In contrast, an index based on advertised rents reports changes in the level of new rental contracts. Since residential mobility was very high as compared to today (see Appendix A, section Residential Mobility) and the absence of tenant protection laws until 1915, one would expect only minor deviations between existing and new contracts. Hence, our results are very reassuring.
} 


\subsection{Geo-coding}

The advertisements contain postal addresses, which we geo-coded in order to obtain geographical coordinates in the form of longitudes and latitudes. As the currently available algorithms for automatic geo-coding exclusively rely on contemporaneous addresses, we had to perform the geo-coding manually. Over the past century, addresses - especially in the former periphery of the city - changed substantially: new streets emerged, while many old streets were merged, split, abolished, or renamed. For example, in Novaya Derevnya (Primorskiy district), the layout of streets changed completely. To identify locations, we used various sources of information including historical maps, ${ }^{10}$ address directories, Google Maps, Yandex Karty, ${ }^{11}$ and, as a last resort, any other information on the history of streets we could find online.

The precision of every geo-coded address depends on whether the house still exists and can be uniquely identified, in which case we can exactly determine its geographical position, or whether the house has been demolished. In the latter case, the geo-coded location is an approximation, and longitudes and latitudes may be misplaced along the respective street section.

\section{A Rent Price Index for St. Petersburg}

We compile a hedonic rental price index in continuous time (Waltl, 2016a). Due to the rather low numbers of observations per year and the large geographical variation of rents within St. Petersburg, we include time as well as location (Hill and Scholz, 2017; Waltl, 2016a,b) as smooth, non-linear effects into the hedonic model. This semi-parametric approach minimizes the influence of choices regarding the functional form of these crucial components as well as bias due to pre-determined temporal (time dummies) and geographical (region dummies) clustering. We apply state-of-the art spatial-econometric techniques to filter out the time trend net of changes in characteristics, i.e., a pure price index.

As benchmarks, we compile two standard hedonic time-dummy indices (annual and quarterly) and a repeat-rent index. All indices identify very similar general trends, but the time-continuous index provides more stable but still detailed information. This level of detail is needed to rigorously analyze the impact of the rent control policy.

In the following, we describe the major steps of our methodology. Technical details about the construction of the continuous as well as the benchmark indices are provided in Appendix B.

\footnotetext{
${ }^{10}$ See http://www.retromap.ru/m.php and http://www.etomesto.ru/peterburg/ (accessed on October 8, 2018).

${ }^{11}$ See https://yandex.ru/maps (accessed on October 8, 2018).
} 
We estimate the hedonic model, which we call the principal model,

$$
\begin{aligned}
\log r=\alpha & +\beta^{\text {rooms }} \text { rooms }+\beta^{\text {type }} \text { type }+\beta^{\text {bath }} \text { bathroom } \\
& +\beta^{\text {fur }} \text { furnished }+\beta^{\text {heat }} \text { heating }+\beta^{\text {elec }} \text { electricity }+\beta^{\text {balc }} \text { balcony } \\
& +f(\text { time })+g_{b i}(\text { long }, \text { lat })+\varepsilon,
\end{aligned}
$$

where $r$ denotes the monthly rent in Russian rubles, $\alpha$ an intercept, rooms a continuous variable indicating the number of rooms, and bathroom, furnished, heating, electricity, and balcony dummy variables indicating whether there is a bathroom, the apartment is furnished, there is electricity within the apartment, heating is provided by the landlord, and whether there is a balcony, respectively. The variable type distinguishes between advertisements referring to an entire apartment and those for a room in a shared apartment. The components $f($ time $)$ and $g_{b i}($ long,lat) model time and location smoothly. The locational function $g_{b i}($ long, lat $)$ is updated biennially to account for distinct price developments across space and changes in local amenities. Finally, $\varepsilon$ is a normally distributed error term.

Due to the smooth components, the principal model (1) becomes an Additive Model (Hastie and Tibshirani, 1987), which is estimated via penalized least squares. The smooth functions in time and geographic co-ordinates are determined following an agnostic approach: no functional forms are assumed; in fact, the functional form is extracted from the data and estimated by finding an optimal compromise between model goodness-of-fit and model smoothness. Hence, the model filters out trends, while penalizing overly wiggly outcomes.

Estimation results are reported in Table 2. All structural characteristics are significant and the signs of estimated shadow prices thoroughly follow expectations: the existence of amenities such as a balcony or provided heating increases the monthly rent. The rent also increases with each additional room. An alternative specification that models the number of rooms as categorical variables (as sometimes done in the literature) leads to very similar estimated effects for the most common cases of one to five rooms. As expected, the monthly rent is lower when it is not an entire apartment but rather a room in a shared apartment that is being rented out. ${ }^{12}$ The smooth functions $f$ and $g_{b i}$ are highly significant as are the updates of the locational function. ${ }^{13}$

In addition, Table 2 reports results for three alternative specifications. The alternatives differ only in

\footnotetext{
${ }^{12}$ Note that advertised rooms in a shared apartment always have a total room number equal to one. Thus, as expected, renting a room in a shared apartment is cheaper than renting a one-room apartment.

${ }^{13}$ We have some information to directly measure the attractiveness of an apartment's location: we collected data on the exact location of restaurants and temples for the years 1894, 1905, 1915, and 1917, then calculated the number of restaurants and temples, respectively, within walking distance (defined as within $1 \mathrm{~km}$ ). We expected that the positive price effect of being close to a temple or a restaurant decreases with the number of such amenities in the immediate neighborhood due to substitution effects. Hence, we included the number of temples and restaurants as smooth functions and found strong evidence for such a diminishing effect. Since the non-parametrically estimated functional form almost perfectly matched a $\operatorname{logarithm}$, we included $\log ($ no. restaurants $)$ and $\log ($ no. temples $)$ into all model specifications. The effects were only modestly significant in the alternative models (A), (B), and (C). In the principal model, the effects were insignificant indicating that the regularly updated spline is able to capture the attractiveness of the location and no further locational information is needed.
} 
Table 2: Hedonic Models: Estimation Results

\begin{tabular}{|c|c|c|c|c|c|c|c|c|}
\hline \multirow[b]{2}{*}{ Intercept } & \multicolumn{2}{|c|}{ Principal model } & \multicolumn{2}{|c|}{ Alt. (A) } & \multicolumn{2}{|c|}{ Alt. (B) } & \multicolumn{2}{|c|}{ Alt. (C) } \\
\hline & 2.656 & $* * *$ & 2.703 & *** & 2.120 & $* * *$ & 2.244 & $* * *$ \\
\hline Rooms & 0.236 & $* * *$ & 0.235 & $* * *$ & 0.239 & $* * *$ & 0.238 & $* * *$ \\
\hline Type $=$ Room & -0.105 & $* * *$ & -0.117 & $* * *$ & -0.080 & $* * *$ & -0.106 & $* * *$ \\
\hline Bathroom & 0.125 & $* * *$ & 0.124 & $* * *$ & 0.140 & $* * *$ & 0.133 & $* * *$ \\
\hline Furnished & 0.246 & $*$ & 0.203 & . & 0.241 & $*$ & 0.274 & $* *$ \\
\hline Heating & 0.170 & $* * *$ & 0.173 & $* * *$ & 0.177 & $* * *$ & 0.171 & $* * *$ \\
\hline Electricity & 0.115 & $* * *$ & 0.117 & $* * *$ & 0.119 & $* * *$ & 0.098 & $* * *$ \\
\hline Balcony & 0.061 & $*$ & 0.088 & $* *$ & 0.070 & $*$ & 0.077 & $* *$ \\
\hline Location & \multicolumn{2}{|c|}{ Spline } & \multicolumn{2}{|c|}{ Spline } & \multicolumn{2}{|c|}{ Districts } & \multicolumn{2}{|c|}{ Districts } \\
\hline Update & \multicolumn{2}{|c|}{ Biennial } & \multicolumn{2}{|c|}{ No } & \multicolumn{2}{|c|}{-} & \multicolumn{2}{|c|}{-} \\
\hline Time & \multicolumn{2}{|c|}{ Spline } & \multicolumn{2}{|c|}{ Spline } & \multicolumn{2}{|c|}{ Year dummies } & \multicolumn{2}{|c|}{ Quarter dummies } \\
\hline Adj. $R^{2}$ & \multicolumn{2}{|c|}{$74.1 \%$} & \multicolumn{2}{|c|}{$72.0 \%$} & \multicolumn{2}{|c|}{$70.4 \%$} & \multicolumn{2}{|c|}{$71.9 \%$} \\
\hline Expl. deviance & \multirow{2}{*}{\multicolumn{2}{|c|}{$\begin{array}{l}75.6 \% \\
3442.9\end{array}$}} & \multicolumn{2}{|c|}{$72.4 \%$} & \multicolumn{2}{|c|}{$70.7 \%$} & \multicolumn{2}{|c|}{$72.9 \%$} \\
\hline $\mathrm{AIC}$ & & & \multicolumn{2}{|c|}{3578.9} & \multicolumn{2}{|c|}{3826.3} & \multicolumn{2}{|c|}{3659.3} \\
\hline
\end{tabular}

Notes: The table reports estimation results from the hedonic models. Results for the principal model (including locational and temporal splines with updates) are shown next to an alternative without updates as well as results from standard annual and quarterly time-dummy models including district dummies to account for locational effects. Significance codes: '***' if the $p$-value is lower than 0.001 , '**' if the $p$-value is lower than ' 0.01 ', '*' if the $p$-value is lower than 0.05 , '.' if the $p$-value is lower than 0.1 and ' ' otherwise.

the way they model location and time. The alternative model (A) models time and location smoothly, but the locational function is kept constant over time. Thus, this model assumes that all locations within St. Petersburg follow the same price trend and that only the level of rents varies across space.

The alternative models (B) and (C) model time and location via dummy variables. Model (B) includes annual and model (C) quarterly time dummies. The time dummies and district dummies are jointly significant, whereas a large number of individual dummies are not. In particular, time dummies referring to periods of rather stable rental prices are often insignificant.

A standard time-dummy index is constructed from the estimated coefficients associated with time dummies as they are included in the alternative models (B) and (C). In an analogous way, the continuous index is obtained from the smoothly estimated time effect.

All model modifications reported in Table 2 have, as one would expect, hardly any effect on the point estimates for structural characteristics and their significance. ${ }^{14}$ The principal model, however, clearly outperforms all other models regardless of which measure is used (adjusted $R^{2}$, AIC or deviance explained). The model is able to explain roughly $74 \%$ of variation within the data. Even more importantly, the principal model yields a sufficiently stable but still detailed rent price index, which allows us to precisely test the impact of the rent control policy in the subsequent section.

\footnotetext{
${ }^{14}$ Per construction, intercepts differ across specifications due to distinct normalization concepts when using splines and categorical variables. For instance, $g$ (long, lat) measures deviations in spatial shadow prices from the average price of location, whereas district dummies measure deviations from the shadow price of one particular district. These differences in normalization are captured by the intercept.
} 
Figure 2: Rent Indices
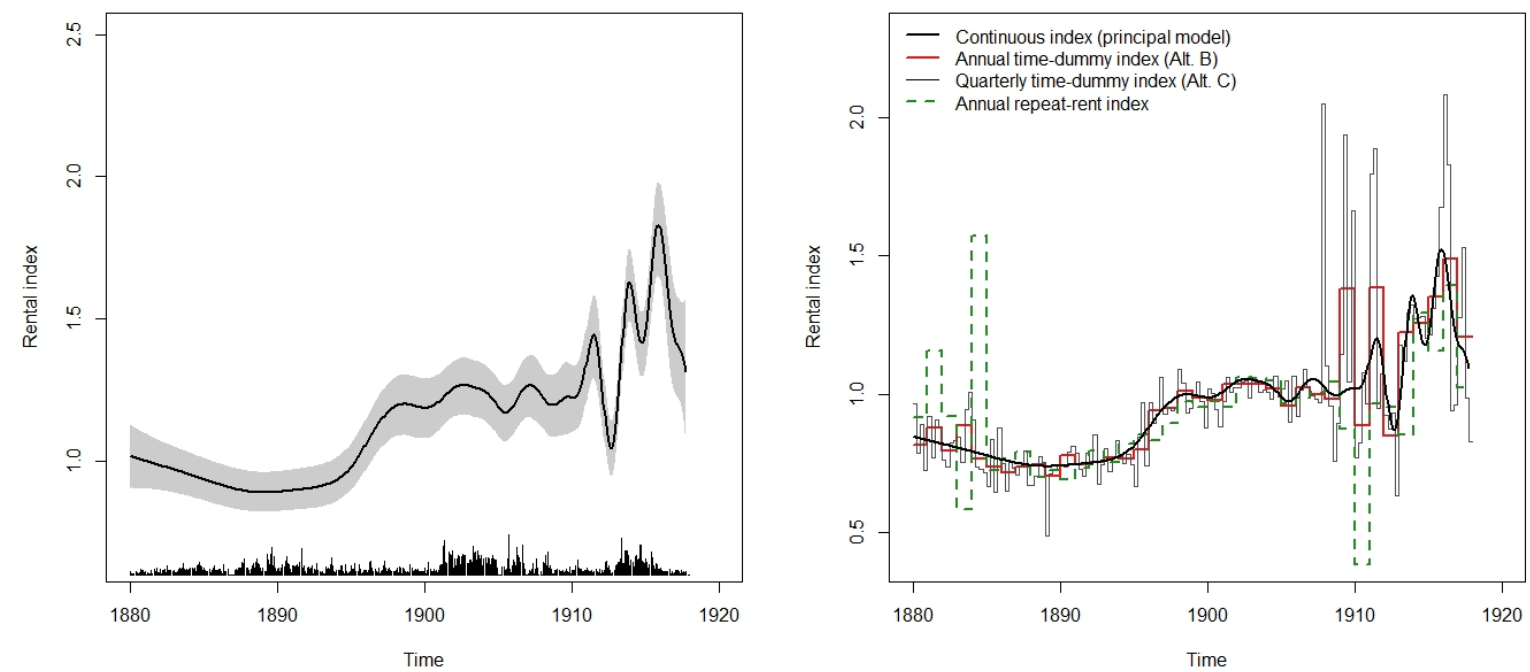

Notes: The left panel shows the continuously estimated index together with $95 \%$ point-wise confidence intervals and, at the bottom of the panel, densities indicating the number of rental advertisements over time. The index is normalized to the average over 1880-1882. For comparison, the right panel shows annual and quarterly timedummy indices implied by the alternatives models $(\mathrm{B})$ and $(\mathrm{C})$, and an annual repeat-rent index. Here, the indices are normalized to the average over 1904-1906 due to the wiggliness of the repeat-rent index in the first years.

Figure 2 shows the continuously estimated index obtained from the principal model $^{15}$ as well as standard annual and quarterly time dummy indices obtained from the alternative models (B) and (C). In addition, a repeat-rent index is depicted. During the first 25 years of the period of observation, all indices follow the same general trend in housing rents. (Except the repeat-rent index reports some large, rather unrealistic price jumps during the first years.) Thereafter, rents become more dynamic and larger deviations are observed. The quarterly time-dummy index is unrealistically wiggly and prone to some extreme jumps. A closer inspection of these cases reveals that the jumps are regularly driven by a few observations with large leverage. The annual index, in contrast, obscures some movements in rents as it estimates average changes from one year to the next. For instance, shortly before the October 1917 revolution, strongly pronounced up- and down-swings are observed in the quarterly time-dummy and the continuous index alike, whereas the annual time-dummy index fails to detect them. The continuously estimated index seems to find a good compromise between smoothness and detection of all relevant turning points.

It is noticeable that the annual and the continuous index are still volatile. Nicholas and Scherbina (2013) also find such high volatility for prices during the roaring twenties and the Great Depression in Manhattan, which refers to a similar overall economic situation. They find that prices peaked in 1929

\footnotetext{
${ }^{15}$ The continuous index can be evaluated at any given frequency. Figure 2 shows a monthly evaluated index.
} 


\section{Figure 3: The Shadow Price of Location}

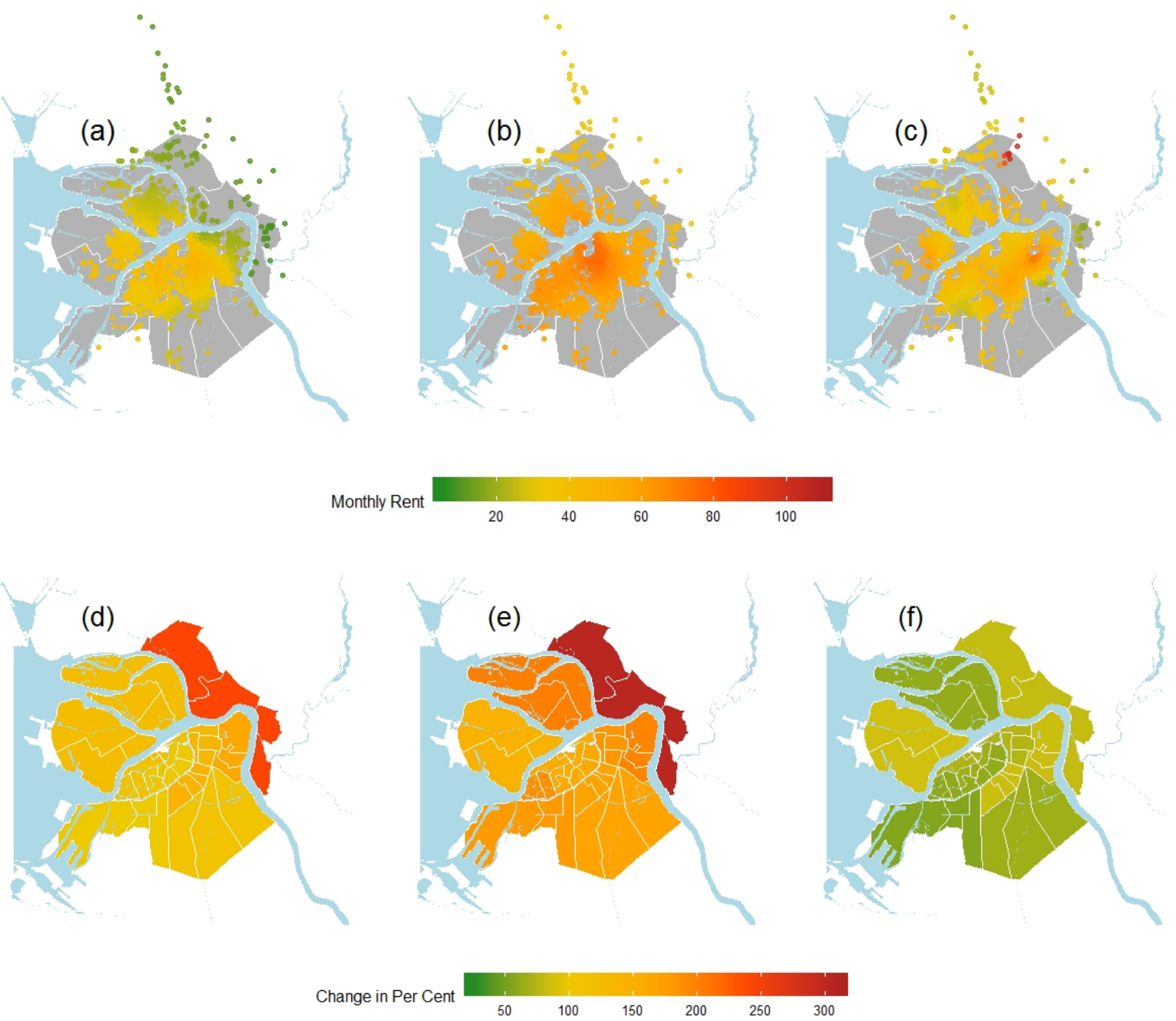

Notes: Panels (a) to (c) show monthly imputed constant-quality rents from the principal model for a furnished apartment with two rooms, a bathroom, no balcony, no heating, and no electricity. Panel (a) refers to 1880, panel (b) to December (November) 1915 when the rent control policy was introduced in St. Petersburg, and panel (c) to October 1917. Panels (d) to (f) show changes in average monthly rents per district in per cent. Panel (d) shows the change over the entire period of observation, panel (e) shows the change between 1880 and the introduction of the rent control policy, and panel (e) shows the change between the introduction of the rent control policy and October 1917.

and dropped by $67 \%$ in 1932 . For St. Petersburg, we find that rents peaked in December 1915 and were down by roughly $50 \%$ on the eve of the October 1917 Revolution.

The principal model (1) enables an analysis of the evolution of rents over space. ${ }^{16}$ Figure 3 shows differences in constant-quality rents over space and time. The overall change in rental prices was most pronounced in the north-eastern district Vyborgskaya, a district with a large share of workers. Highest

\footnotetext{
${ }^{16}$ Note that updating locational dummy variables in the models $(\mathrm{B})$ and $(\mathrm{C})$ is not feasible as the resulting number of parameters is unsustainably large, which is why the alternative models are not suited for this purpose.
} 
rents are observed in the inner districts, which is in line with census data (see Figure A.15). ${ }^{17}$

\section{Figure 4: The Rent Index Put into Perspective.}

(a)

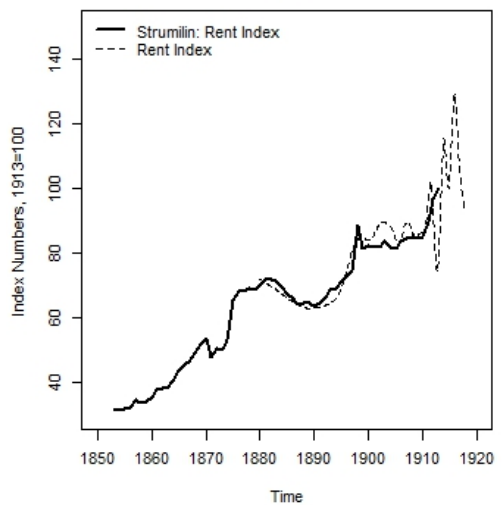

(d)

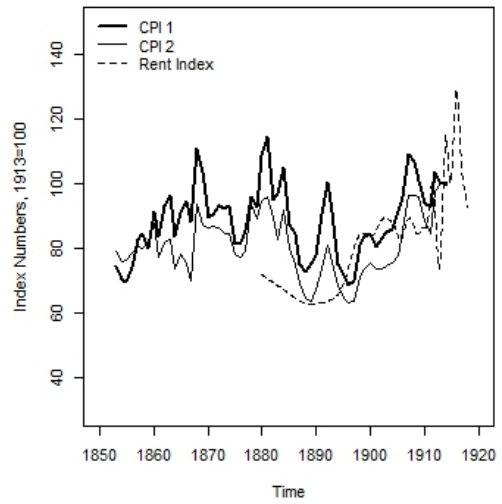

(b)

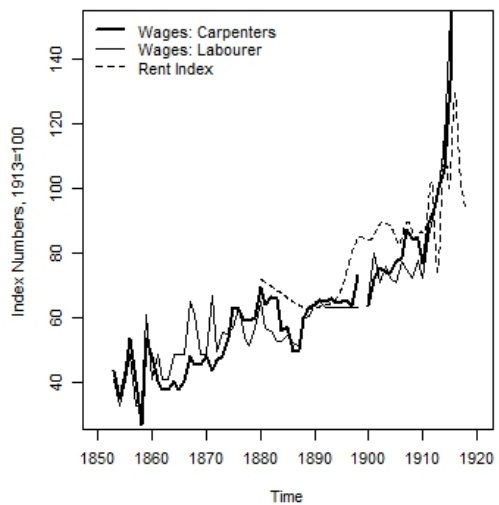

(e)

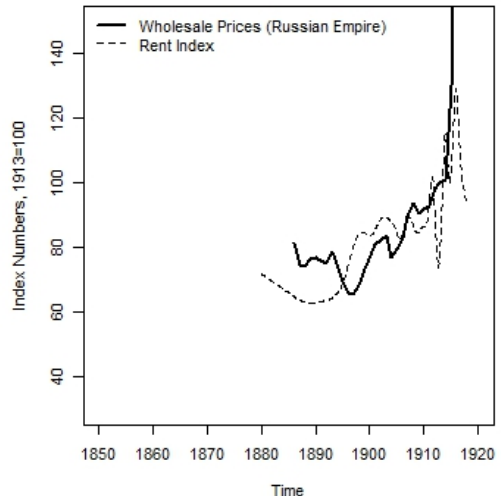

(c)

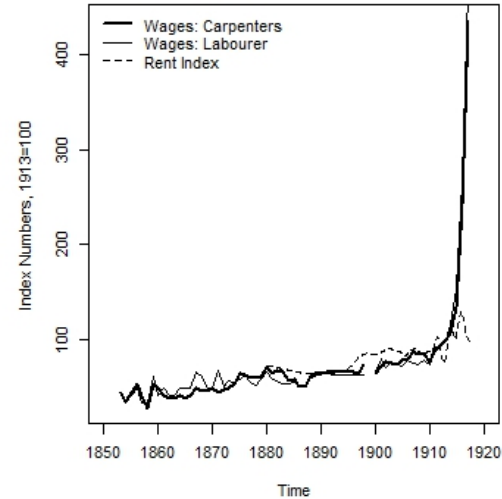

(f)

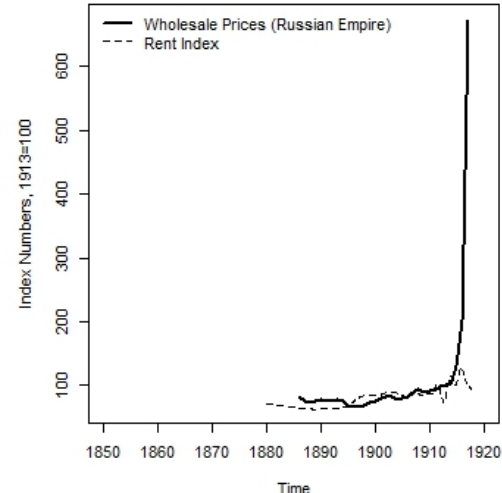

Notes: The figures compare the hedonic rent price index to related series. Additional to the rent index, panel (a) depicts an alternative rent index (Strumilin, 1966). Panels (b) and (c) show wage series for carpenters and building laborers (Allen and Khaustova, 2018). For better readability, the $y$-axis is capped in panel (b). Panel (d) shows two CPIs using the subsistence basket approach developed by Allen (2001). The two series differ in the way how they measure prices for bread products: CPI 1 relies on prices for flour, while CPI 2 directly uses prices for bread. Panels (e) and (f) depict a wholesale price index referring to the entire Russian Empire (Pervushin, 1925).

In Figure 4, we compare the hedonic rent index to a cost of rental accommodation index compiled by the Soviet economist V. L. Dalmatov and documented in Strumilin (1966). ${ }^{18}$ The index ends in 1913. Until then, the indices are strikingly similar, which supports our argument that rental advertisements are indeed representative for describing price movements in the entire market.

\footnotetext{
${ }^{17}$ Another expensive district, according to the census, is the north-western part of district Peterburgskaya, where the summer residences of the wealthier inhabitants were located. Unfortunately, our sample contains hardly any observations from there, which is why we can neither confirm nor reject this.

${ }^{18}$ Unfortunately, the applied index construction methodology is opaque. Strumilin notes that decennial census data are the major ingredient of this index; however, we could not find any information on how annual index numbers are obtained from decennial data.
} 
Additionally, we compare the rent index to nominal wage and CPI series compiled by Allen and Khaustova (2018). As Allen and Khaustova's CPI series end in 1913, we also plot a wholesale price index referring to the entire Russian Empire (see Pervushin, 1925).

All indices find a general upward trend from roughly 1890 onward. The indices that go beyond 1913 accelerate strongly before the October Revolution. This is true for wages and prices. At first, rents follow the same trend with very similar appreciation rates. However, this trend is reversed at the end of 1915 - just when the rent control policy was introduced. Given the explosive increases of other prices, this turning point is remarkable. In section 4, we analyze this turning point in the light of the rent control policy.

\section{Rent Control and Tenant Protection}

\subsection{The Design of the Policy}

In the Russian empire prior to World War I, there were no policies regulating rent increases or the eviction of tenants. Such policies were only introduced during World War I, when excess demand for housing, caused by war-related massive population movements, led to a housing crisis. In particular, a loss of large territories in the first half of 1915 led to large flows of refugees ${ }^{19}$ and evacuated civilians as well as government bodies and educational institutions toward interior regions. In our data, we do indeed find large increases in rents after the outbreak of the war.

Local authorities (more precisely, civilian heads of governorates and commanders-in-chief of the military districts) reacted to rising rents by issuing "compulsory ordinances" (obyazatel'noe postanovlenie): for the first time in Russian history, laws were put into place seeking to protect tenants from rent increases and, later, also from unjustified evictions. Alone in the summer of 1915, 20 governorates and three military districts, which typically encompassed several governorates, introduced rent control policies. By August 1916, rent regulations were implemented in at least 88 out of the 101 administrative regions (governorates and oblasts) that comprised the Russian Empire at the outbreak of World War I. ${ }^{20}$

In St. Petersburg, such a compulsory ordinance was issued on December 9 (November 26), 1915 by the commander-in-chief of the Petrogradskiy military district. It froze rents for apartments, rooms, corners, and beds ex post at the January 14 (1), 1915 level. Rents could only be increased to offset rising cost of fuel and house personnel as well as in case of a large refurbishment of the house. The rental contract was prolonged automatically as soon as the tenants regularly paid the rent.

By fall 1916, the national authorities took over the task of regulating the rental market. On September 9 (August 27), 1916, the Council of Ministers issued an act prohibiting rent increases. The major features of the regulation were the same as those of the 1915 policy in St. Petersburg: in principal, the rent was

\footnotetext{
${ }^{19}$ Estimates about the total number of refugees in the Russian Empire during World War I range between 5 and 15 million (see Mihaliov and P'yankov, 2015, p. 103).

${ }^{20}$ For more details see also Kholodilin (2017).
} 
frozen at the January 14 (1), 1915 level. Only if the contract was concluded before August 1 (July 19), 1914 the rent could be increased but not by more than 10\%. Any other increases were forbidden and could even be punished with a prison sentence.

The national policy again included a tenant protection component. It required landlords to prolong rental contracts for one year if the tenant requested an extension no later than one month prior to the end of the contract for apartments or one week for rooms. Contracts were extended under the same conditions. Low-income tenants who rented beds or room corners were automatically granted extensions, as long as they were paying their rent. Eviction was prohibited, except for the three following cases: if the tenant infringed contract conditions; if the landlord proved that he needed the dwelling for himself and his family members; or if the tenant's behavior made normal cohabitation with other tenants impossible.

Expensive apartments were excluded from rent control. In St. Petersburg, a dwelling was considered expensive if the annual rent (excluding heating costs) exceeded 2,400 rubles. Given that the majority of dwellings had a lower rent, the regulation can be seen as a social policy targeted toward protecting members of the lower classes. ${ }^{21}$

On August 18 (5), 1917, the Russian Provisional Government issued an act that set new upper bounds on rents in the form of maximum percentage increases of the pre-war rent, i.e., before August 1 (July 19), 1914. These increases were progressive and depended on the settlement (all settlements - cities, market towns, villages, etc. - were categorized into four classes based on the direct tax schedule): the higher the initial rent, the higher the allowed percentage increase. Hence, tenants of cheaper apartments could expect smaller rent increases as opposed to tenants of more expensive units. There was a general cap equal to an increase of $100 \%$.

Soon after the issuance of this act, the October Revolution kicked in and the private rental market vanished. The period where the policy was in place is too short to perform a rigorous empirical analysis.

\subsection{The Impact on Rents and Residential Mobility}

The 1915 rent control policy had strong effects: it reversed the trend of rapidly rising rents and increased the tenure duration. The second policy introduced less than a year later and covering the entire Empire is essentially an extension of the 1915 policy as the principal features remained identical. We, thus, expect no explicit reaction in the market, which is also what we find.

The city-wide policy was introduced on December 9 (November 26), 1915. Rents immediately dropped and the January 14 (1), 1915 level was reached again in December 1916 as indicated in the right panel of Figure 5. After reaching the level targeted by the policy, the decrease in rental prices slowed down, before slightly accelerating again later in 1917 - the year of two revolutions.

We perform an event study to formally test, whether changes in the index are fundamentally different

\footnotetext{
${ }^{21}$ The average annual advertised rent in 1915 was 740 rubles (median: 600 rubles) only. In 1914/1915/1916, only $7 / 2 / 3$ advertisements asked for a rent exceeding 2,400 rubles, respectively.
} 
Figure 5: Rent Index and Major Events

1880-1917

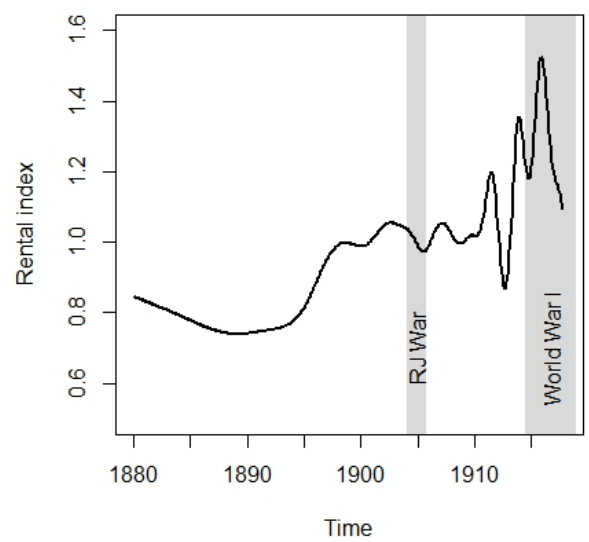

1911-1917

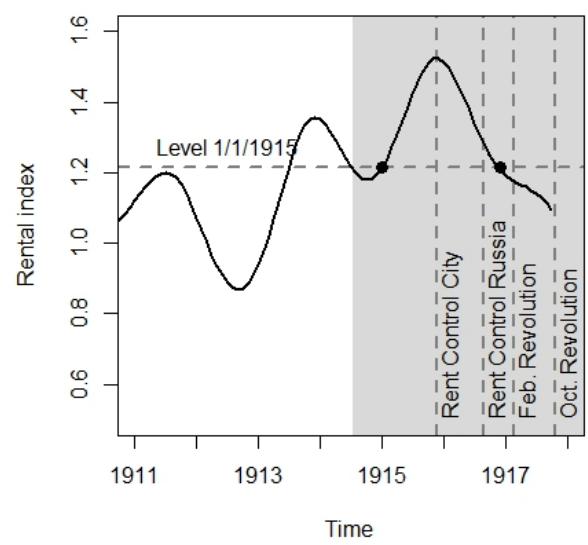

Notes: The figure shows the rent index together with the timing of major events (see Appendix A.2 for details) and the introduction of the rent control policies. The left panel shows the entire time span, whereas the right panel focuses on 1911 to 1917.

after the introduction of the policy as compared to "normal times."

Figure 6: Monthly Changes in the Rental Index

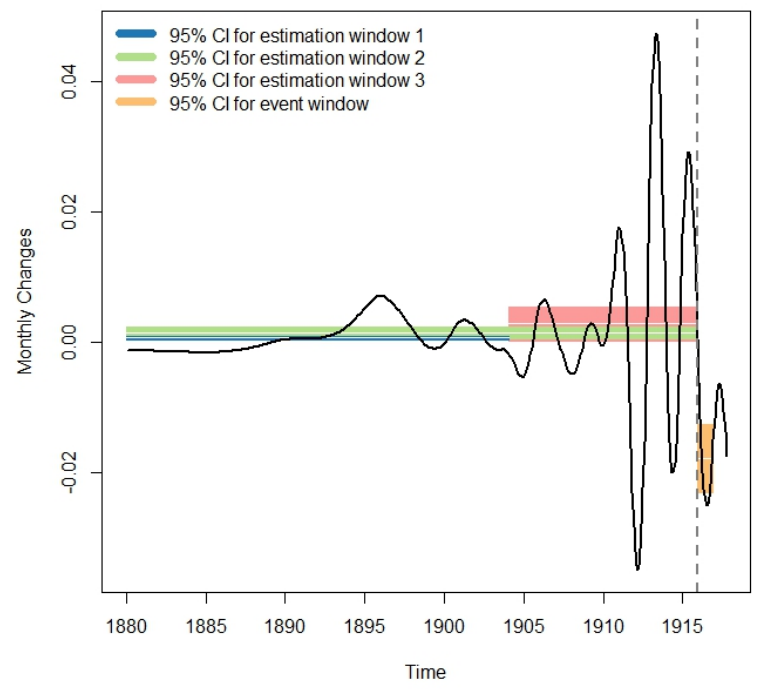

Notes: The figure shows monthly changes in rental prices and emphasizes average changes together with $95 \%$ confidence intervals during "normal times" (defined via three different estimation windows) and the "event window." The gray-dashed line marks the introduction of the rent control policy in St. Petersburg in 1915.

It is far from obvious how to define "normal times," given that the period before the introduction of the policy is characterized by an extraordinary event, World War I. We, thus, rely on three different 
definitions of "normal times" from which a "normal" monthly change in rental prices is computed. First, we consider the time span between 1880 and the start of the Russian-Japanese War; second, the period between 1880 and the introduction of the rent control policy; and, third, the time span between the Russian-Japanese war and the introduction of the rent control policy (see Figure 6). We compare average changes in "normal times" to average changes following the introduction of the rent control policy. More precisely, we look at the one year period following the introduction of the city-wide policy, thus, also covering the policy targeting the entire Russian Empire. The latter period is usually referred to as the "event window," whereas the period of "normal times" is referred to as "estimation window."

Regardless of the period of comparison, the changes observed after the introduction of the policy are significantly lower. ${ }^{22}$ In fact, average monthly changes in "normal times" are close to zero, whereas after the introduction of the policy, changes are clearly negative. The timing of this change fits the policy's issuing date very well.

We also exploit the fact that several rental units appear on the market multiple times to test for changes in landlords' (asking) rent setting behavior and compliance with the policy. ${ }^{23}$

Figure 7 depicts price pairs of rental units advertised at least twice between 1914 and December 9 (November 26), 1915, or between the issuance date of the rent control policy and the start of the October Revolution. After the introduction of the policy, not a single pair indicates a price increase. In fact, all rents remained at the same level. This pattern is in sharp contrast to what happened before the issuance of the policy: rents for the same units were regularly adjusted in both directions, even over the short period of two years. On average, rents were rising before the introduction, but there was, in fact, substantial variation.

Any rental unit advertised after December 9 (November 26), 1915 falls under the rent control policy. Only expensive units with an annual rent exceeding than 2,400 rubles were exempt from fall 1916 onward. There is indeed one rental unit with such a high rent that was advertised twice after the introduction of the rent control policy. Although this apartment was exempt from the policy, we still do not observe a price increase.

Figure 7 only depicts price pairs for which both advertisement dates were either before or after the policy. There are four price pairs overlapping the policy, i.e., a first advertisement before and a readvertisement after the introduction of the policy. Three of them were re-advertised only days after the introduction of the policy. It is unclear how quickly the policy was communicated or whether landlords

\footnotetext{
${ }^{22}$ Comparing confidence intervals is equivalent to performing a Welch's $t$-test on differences in means, which requires the assumption of normality. The Welch test rejects the null hypothesis of equality in means for all definitions of the estimation window ( $p$-values are consistently smaller than the machine epsilon). A Wilcoxon Rank Sum Test, a nonparametric alternative, also finds significant differences regardless of the definition of the estimation window ( $p$-values are again consistently smaller than the machine epsilon).

${ }^{23}$ We identify repeated observations by matching advertisements on their exact address as well as all structural characteristics available. Repeated units do not differ systematically from uniquely advertised observations: structural characteristics and their locational dispersion are very similar. On top, the repeat rents index tracks price changes measured from the overall sample very closely. More details are provided in Appendix B.3.
} 


\section{Figure 7: Repeated Observations: Price Changes}

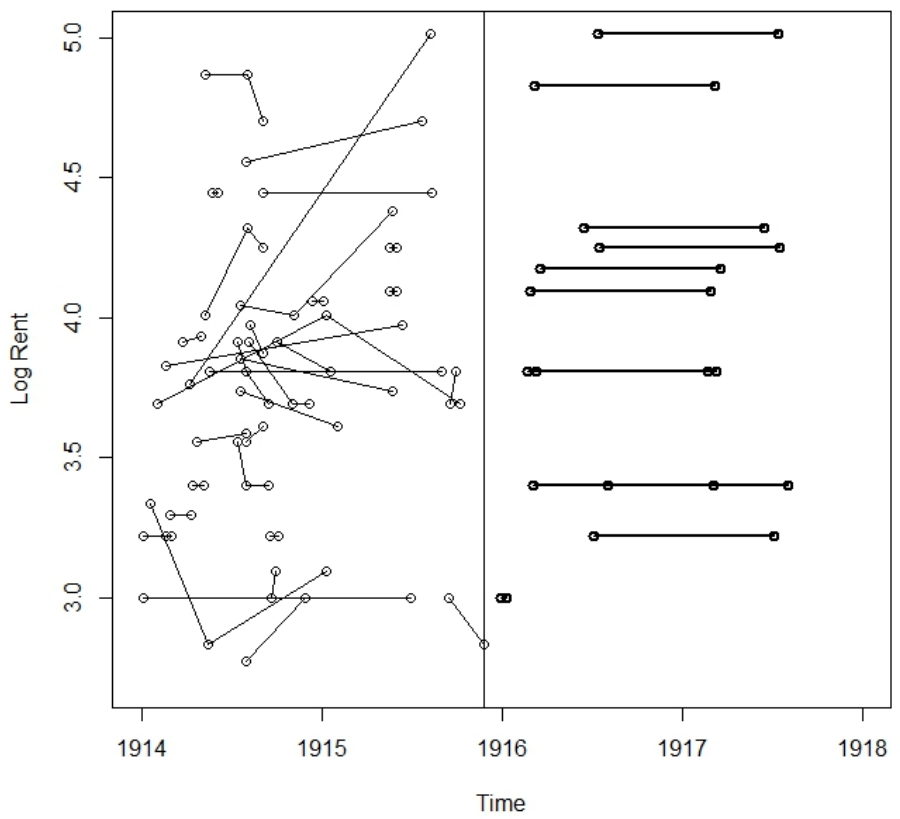

Notes: The figure plots bilateral price pairs (logged monthly rents) of rental units advertised at least twice between 1914 and December 9 (November 26), 1915, or between the issuance date of the policy and the start of the October Revolution. There are 42 pairs before and 13 pairs after the introduction of the policy.

were expecting immediate execution of the policy. Two of these price pairs report increases and one a decrease in rents. The fourth pair was originally advertised in 1914 and also reports a rent increase. This is the only case that might document non-compliance with the policy. (As we do not have explicit information on the rent as of January 1915 - the landlord might have increased it without re-advertising the apartment - even this observation may not necessarily document non-compliance.)

Thus, there is strong evidence that - at least officially - the policy triggered a change in behavior among landlords and had a stabilizing effect: we find no evidence for rent increases after the issuance of the policy, which is exactly what the policy aimed for. Additionally, the ex post freezing of the rent as of January 14 (1), 1915 successfully pushed downward the overall rent level.

We identify a clear price effect associated with the policy and evidence for general compliance with the policy. However, the data we rely on uses publicly advertised rents. How sure can we be that what is officially asked for reflects the true price burden renters were facing? Both policies foresee rather harsh punishments in the case of non-compliance: landlords faced a potential fine of up to 3,000 rubles or a prison sentence of up to three months. This was not just an empty threat. Petrogradskaya gazeta writes about several landlords who were punished for such infractions, e.g., on January 16 and 25 (3 and 12), 1916. However, we do not find hints documenting non-compliance on a large scale. 
Another article published in Petrogradskaya gazeta on August 29 (16), 1916 suggests a different strategy of landlords to earn more than the officially allowed rent: the article tells the story of a person who unsuccessfully searched for an apartment to rent for four weeks. He was advised to place an advertisement that promised a financial compensation to anyone who would find him a place to live. Within a day, he received 25 offers. We cannot be sure whether such strategies were common practice. Even if so, such kind of agent fees or key money are one-time payments and, thus, should not impact monthly rent significantly, especially when the tenants are protected from eviction.

Table 3: Residential Mobility and Tenure Duration

\begin{tabular}{ccccc}
\hline \hline Years & $\begin{array}{c}\text { Stay } \\
\text { (individuals) }\end{array}$ & $\begin{array}{c}\text { Move } \\
\text { (individuals) }\end{array}$ & Mobility & $\begin{array}{c}\text { Duration } \\
\text { (years) }\end{array}$ \\
\hline $1912-1913$ & 242 & 100 & 0.292 & 3.420 \\
$1913-1914$ & 255 & 96 & 0.274 & 3.656 \\
$1914-1915$ & 253 & 102 & 0.287 & 3.480 \\
$1915-1916$ & 262 & 83 & 0.241 & 4.157 \\
$1916-1917$ & 293 & 67 & 0.186 & 5.373 \\
\hline \hline
\end{tabular}

Notes: The table reports the number of sampled individuals that stayed at the same address from one year to the next as well as the number of those who changed their address. From these numbers, we calculate annual mobility rates and their reciprocal values, which describe the average tenure duration in years.

The regulation also contains a tenant protection component, and, indeed, we also find empirical evidence for an increase in tenure duration. It is fair to assume that, without protection, every year a positive fraction of renters changed their address involuntarily and that a positive fraction of those people would have paid their rent regularly. From end of 1915 onward, those renters were protected from eviction. Since rents fell following the introduction of the policy, an even larger fraction of renters are ceteris paribus able to pay the rent and, thus, fall under the target population of the policy. Hence, the policy is expected to lead to a decrease in residential mobility or, equivalently, an increase in tenure duration via two channels. We find evidence for decreasing residential mobility, hence concluding that the policy indeed improved tenant protection.

Table 3 reports annual mobility rates computed as the share of people who changed their address from one year to the next within a representative sample (see also Appendix A, section Residential mobility). ${ }^{24}$ While the residential mobility rate equaled roughly 0.28 prior to 1915, it fell to 0.24 in 1916 and dropped

\footnotetext{
${ }^{24}$ We impute the mover rate from annual address directories (adresnaya kniga) in St. Petersburg (e.g., for 1912 and 1913 : Suvorin, 1912, 1913). The directories contain information on a person's surname, first name, father's first name, social status (e.g., noble or honorary citizen, or daughter, wife, or widow of a noble or honorary citizen), rank and profession, telephone number, as well as postal address. The ample information allows us to unambiguously identify individuals and track them over time. About 140,000 persons are included in these directories, which constitutes roughly $7 \%$ of the population (city and outskirts). These directories are representative for the middle and upper class, including military officers, police officers, civil servants, merchants, shopkeepers, physicians, architects, and the aristocracy. For our calculations, we take all persons with surnames from Aaronov through Abramskiy who appear in the directories in two consecutive years, which yields between 340 and 360 observations in each sample. The residential mobility is computed as the share of movers in the total sample.
} 
even further to 0.19 in $1917 .{ }^{25}$ The average duration to stay at the same address (the inverse mobility rate) increased from roughly 3.5 years to more than 5 years.

\subsection{Rent Affordability Before and After the Issuance of the Policy}

To put the level of rents into perspective, we impute constant-quality rent-to-wage ratios as a measure of affordability. We use annual wages earned by carpenters and building laborers (collected by Allen and Khaustova, 2018) and compare them to imputed rents. We impute the price for a standardized rental unit for different points in time and St. Petersburg's workers' districts Alexandro-Nevskaya, Narvskaya, and Vyborgskaya. Thus, changes in rents are not affected by changes in characteristics.

Analyzing the structural characteristics of advertised rentals in these districts reveals that the units were almost always furnished apartments that had no balcony and no electricity. Usually, these apartments did not have a bathroom and did not include heating. On average, the apartments had three rooms. ${ }^{26}$ Thus, we impute average rental prices for this typical type of apartment. From the principal model (1), we predict rental prices for all geographical co-ordinates we observed in each of the three workers' districts. This yields roughly 100 addresses in each district over which an average is taken.

Carpenters generally earned more than building laborers. However, even for carpenters, it was impossible to rent an entire apartment as the rent would have eaten up their entire monthly wage. Consequently, we assume that a worker would rent at most a room in an apartment rather than an entire apartment and accordingly divide the total imputed rent by three.

Figure 8 depicts the resulting rent-to-wage ratios. For building laborers, rent-to-wage ratios were very high before the issuance of the rent control policy. It is rather unlikely that these workers were indeed renting a room by themselves. Probably, most had to share a room with other workers. This is in line with the high crowding rates per room documented in the censuses (see Appendix A, section Crowding). The situation was better for carpenters.

Mainly due to rising wages, affordability increased from roughly 1913 onward. Wages kept increasing and when rents fell after the introduction of the rent control policy, affordability improved extraordinarily. Never before could workers spend so little of their wage on rents - provided they were able to find a place to live.

If that were the whole story, the years after 1915 would have been a prosperous time for workers in St. Petersburg. However, other goods experienced extraordinary price increases (see Figure 4 and also Allen and Khaustova, 2018) and by October 1917 historians speak of hyperinflation. Thus, we conclude that the regulatory intervention in 1915 had an important effect on reducing the rent burden on workers, but this relief could not offset the economic burden workers experienced due to other price increases.

\footnotetext{
${ }^{25}$ The fall is statistically significant at a $1 \%$ significance level according to a test of equal proportions (Newcombe, 1998).

${ }^{26}$ In Alexandro-Nevskaya, Narvskaya, and Vyborgskaya, respectively, the share of rental units in our data set having exactly these features equals $12 \%, 9 \%$ and $23 \%$, respectively. When ignoring the number of rooms, the shares increase to $35 \%, 58 \%$ and $35 \%$, respectively.
} 
Figure 8: Affordability: Rent-to-Wage Ratios

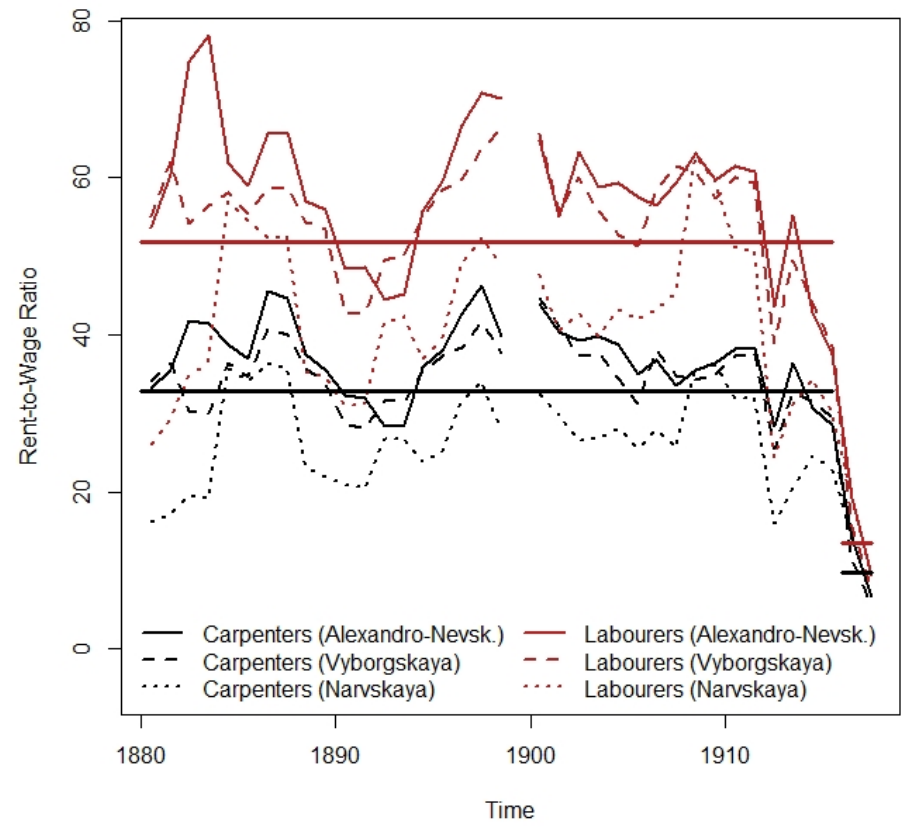

Notes: The figure shows rent-to-wage ratios for carpenters and building laborers, and the three workers' districts Alexandro-Nevskaya, Narvskaya, and Vyborgskaya. The straight lines depict averages over all districts before and after the introduction of the rent control policy. Gaps in the series are due to missing values in the wage data.

Therefore, although the period immediately before the October Revolution was economically challenging for workers, the extraordinary rent increases characterizing the early years of World War I were contained, if not retracted.

\section{Conclusions}

We present a newly assembled data set on rents advertised in newspapers to describe the rental market in St. Petersburg between 1880 and the start of the October 1917 Revolution. In addition to rental prices, we also collect detailed structural characteristics and postal addresses, which we geo-coded. We use this data set to estimate the first market data-based hedonic rent price index for any pre-Soviet Russian housing market. We apply a semi-parametric approach to construct a stable and timely index. The topographic particularities of St. Petersburg are taken account of by including a flexible soap-film smoother defined on longitudes and latitudes into the hedonic model.

This index feeds into an event study that assesses a radical rent control and tenant protection policy introduced in St. Petersburg in 1915 in response to skyrocketing rents following the outbreak of World War I. After the introduction of the policy, rents plunged immediately. We also analyze rental units advertised multiple times and find that landlords stopped their common practice of regularly adjusting 
(asking) rents even over short periods of time once a policy prohibiting any such increases was issued. Additionally, we find that the tenant protection component of the policy increased tenure duration from roughly 3.5 to about five years.

We compare changes in rents to changes in other prices and wages. All indices document a general upward trend from roughly 1890 onward. While general consumer price indices stop in 1913, we have more information on wholesale prices and wages. Both accelerate strongly before the October Revolution. Initially, rents follow the same trend, but the issuance of the rent control policy constitutes a remarkable turning point.

The coincidence of rising wages and falling rents let to a great improvement of rent affordability for the working class population: rent-to-wage ratios were never as low as during the months preceding the October Revolution. However, the economic burden from other prices following an explosive path could not be compensated.

Additionally, a comprehensive appendix brings together ample background information characterizing the historic housing market. This information is complemented by demographic data relevant for our study.

\section{References}

Allen, R. C. (2001). The great divergence in European wages and prices from the middle ages to the first world war. Explorations in Economic History, 38(4):411-447.

Allen, R. C. and Khaustova, E. (2018). Russian real wages before and after 1917. Explorations in Economic History.

Ambrose, B. W., Eichholtz, P., and Lindenthal, T. (2013). House prices and fundamentals: 355 years of evidence. Journal of Money, Credit and Banking, 45(2-3):477-491.

Arnott, R. (1995). Time for revisionism on rent control? Journal of Economic Perspectives, 9(1):99-120.

Autor, D. H., Palmer, C. J., and Pathak, P. A. (2014). Housing market spillovers: Evidence from the end of rent control in Cambridge, Massachusetts. Journal of Political Economy, 122(3):661-717.

Avrukh, L. G. (2004). Телефонизация Петербурга: 1882-1917 г. (Telefonization of St. Petersburg: 1882-1917). Российский государственный педагогический университет имени А. И. Герцена: Диссертация на соискание степени кандидата наук.

Bailey, M. J., Muth, R. F., and Nourse, H. O. (1963). A regression method for real estate price index construction. Journal of the American Statistical Association, 58(304):933-942.

Bonneval, L. and Robert, F. (2012). Peuplement du centre-ville et mobilité des locataires. Lyon, 18911968. Le mouvement social, (2):91-112. 
Brander, S. (1984). Wohnungspolitik als Sozialpolitik. Theoretische Konzepte und praktische Ansätze in Deutschland bis zum Ersten Weltkrieg. Duncker \& Humblot: Berlin.

Carmona, J., Lampe, M., and Rosés, J. (2017). Housing affordability during the urban transition in Spain. The Economic History Review, 70(2):632-658.

Case, K. E. and Shiller, R. J. (1989). The efficiency of the market for single-family homes. The American Economic Review, 79(1):125-137.

Central'nyi Statistichekiy Komitet MVD (1872). Санкт-Петербург по переписи 10 декабря 1869 года. Выпуск первый. Население по возрастам, семейному состоянию, вероисповеданиям, народностям, сословиям и грамотности (St. Petersburg according to the census of December 10, 1869, Population...). Санкт-Петербург: Издание Центрального статистического комитета МВД.

Central'nyi Statistichekiy Komitet MVD (1891). Санкт-Петербург по переписи 15 декабря 1890 года.

Часть 1. Население. Выпуск 1. Численность и состав населения по полу, возрасту, семейному положению, грамотности, вероисповеданию, сословию и родному языку (St. Petersburg according to the census of December 15, 1890, Population...). Санкт-Петербург: Типография Шредера.

Central'nyi Statistichekiy Komitet MVD (1903). Санкт-Петербург по переписи 15 декабря 1900 года. Население. Выпуск 1. Численность и состав населения по полу, возрасту, месту рождения (в С.-Петербурге и вне его), времени поселения в С.-Петербурге, семейному состоянию, грамотности, сословию, вероисповеданию и родному языку (St. Petersburg according to the census of December 15, 1900, Population...). Санкт-Петербург: Типография Шредера.

Central'nyi Statisticheskii Komitet MVD (1914). Города России в 1910 году (Russian cities in 1910). Санкт-Петербург: Типолитография Н. Л. Ныркина.

Central'nyi Statisticheskiy Komitet MVD (1915). Статистический ежегодник Pоссии. 1915 г. (Statistical yearbook of Russia 1915). Петроград: Издание Центрального Статистического Комитета М.В.Д.

Clark, G. (2002). Shelter from the storm: Housing and the industrial revolution, 1550-1909. The Journal of Economic History, 62(2):489-511.

de Haan, J. and Diewert, W. E., editors (2013). Handbook on Residential Property Prices Indices (RPPIs). Methodologies and Working Papers. Eurostat, Luxembourg.

Diamond, R., McQuade, T., and Qian, F. (2018). The effects of rent control expansion on tenants, landlords, and inequality: Evidence from San Francisco. National Bureau of Economic Research.

Eberstadt, R. (1920). Handbuch des Wohnungswesens und der Wohnungsfrage. Jena: Verlag von Gustav Fischer. 
Eichholtz, P., Korevaar, M., and Lindenthal, T. (2018). 500 years of urban rents, housing quality and affordability. Mimeo.

Eichholtz, P., Straetmans, S., and Theebe, M. (2012). The Amsterdam rent index: The housing market and the economy, 1550-1850. Journal of Housing Economics, 21(4):269-282.

Eichholtz, P. M. (1997). A long run house price index: The Herengracht index, 1628-1973. Real Estate Economics, 25(2):175-192.

Eitrheim, O. and Erlandsen, S. K. (2004). House price indices for Norway 1819-2003. In Historical Monetary Statistics for Norway, pages 349-375. Norges Bank, Oslo.

Eliseeva, I. I. and Gribova, E. I. (2003). Санкт-Петербург. 1703-2003: Юбилейный статистический сборник (St. Petersburg. 1703-2003: Anniversary statistical book), volume 2. Санкт-Петербург: Судостроение.

Feldbauer, P. (1979). Wohnungsproduktion am Beispiel Wiens 1848-1934. In Niethammer, L., editor, Wohnen im Wandel: Beiträge zur Geschichte des Alltags in der bürgerlichen Gesellschaft, pages 317343. Peter Hammer Verlag: Wuppertal.

Gray, R. (2015). Rents and welfare in the second industrial revolution: Evidence from New York City.

Hastie, T. and Tibshirani, R. (1987). Generalized additive models: some applications. Journal of the American Statistical Association, 82(398):371-386.

Hill, R. J. (2013). Hedonic price indexes for residential housing: A survey, evaluation and taxonomy. Journal of Economic Surveys, 27(3):879-914.

Hill, R. J. and Scholz, M. (2017). Can geospatial data improve house price indexes? A hedonic imputation approach with splines. Review of Income and Wealth, doi:10.1111/roiw.12303.

Kennedy, P. E. (1981). Estimation with correctly interpreted dummy variables in semilogarithmic equations. The American Economic Review, 71(4):801.

Kholodilin, K. (2017). Housing policy of non-Bolshevik governments during the Russian Civil war. NRU HSE Working paper Series Humanities WP BRP 151/HUM/2017.

Kholodilin, K., Weber, J. P., and Sebastian, S. (2018). Rental market regulation over the last 100 years in an international comparison. DIW Weekly Report, 8(45):453-464.

Kholodilin, K. A. (2016). War, housing rents, and free market: A case of Berlin's rental housing market during World War I. European Review of Economic History.

Knoll, K., Schularick, M., and Steger, T. (2017). No price like home: Global house prices, 1870-2012. American Economic Review, 107(2):331-53. 
Kohl, S. (2017). Homeownership, renting and society. Historical and comparative perspectives. London and New York: Routledge Taylor and Francis Group.

Kosinskaya, A. (2016). Петербург 100 лет назад: как сдавали и снимали жильё до революции (St. Petersburg 100 years ago: how the housing was let and rented prior to the October Revolution). https://paperpaper.ru/spb-100-homes/.

Kruzhnov, Y. N. (2014). История квартирного вопроса в России, или Коммуналки навсегда (Нistory of housing issue in Russia, or shared apartments forever). Санкт-Петербург: Серебряный век.

Limonov, L. E. (1997). Рынок городских земельных участков в Санкт-Петербурге в конце XIX начале XX вв. (St. Petersburg real estate market at the end of the 19th - beginning of the 20th century). In Limonov, L. E., editor, Проблемы становления и регулирования рынков городской недвижимости, pages 191-208. Санкт-Петербург: Наука.

Lyons, R. C. (2018). An index of Dublin housing prices since 1900. Mimeo.

Mannigel, A. and Jackisch, A. (2016). Wie lange leben Hamburgerinnen und Hamburger in ihrer Wohnung? Statistik informiert..., 142:1-2.

Margo, R. A. (1996). The rental price of housing in New York City, 1830-1860. The Journal of Economic History, 56(3):605-625.

McMillen, D. P. (2014). Local quantile house price indices. Mimeo.

Mihaliov, N. A. and P'yankov, S. A. (2015). Беженцы Первой мировой войны в Российской империи: численность, размещение, состав (Refugees of World War I in the Russian Empire: number, allocation, and composition). Уралъский исторический вестник, 49(4):95-105.

Munch, J. R. and Svarer, M. (2002). Rent control and tenancy duration. Journal of Urban Economics, $52(3): 542-560$.

Newcombe, R. G. (1998). Two-sided confidence intervals for the single proportion: comparison of seven methods. Statistics in medicine, 17(8):857-872.

Nicholas, T. and Scherbina, A. (2013). Real estate prices during the roaring twenties and the Great Depression. Real Estate Economics, 41(2):278-309.

Pervushin, S. A. (1925). Хозяйственная конбюнктура: Введение в изучение динамики русского народного хозяйства за полвека (Economic conditions: Introduction to investigating the dynamics of the Russian national economy during half of a century). Москва: Издательство «Экономическая жизнь». 
Raff, D., Wachter, S., and Yan, S. (2013). Real estate prices in Beijing, 1644 to 1840. Explorations in Economic History, 50(3):368-386.

Rashin, A. G. (1956). Население России за 100 лет (1811-1913): статистические очерки (Рориlation of Russia during 100 years (1811-1913): Statistical essays). М.: Государственное статистическое издательство.

Samy, L. (2015). Indices of house prices and rent prices of residential property in London, 1895-1939. University of Oxford, Discussion Papers in Economic and Social History, 134.

Sheremetevskiy, M. (1916). Опыт исследования некоторых данных о населении г. Москвы (An exploration of some data on Moscow's population). Городское дело, 19:885-896.

Silver, M. (2016). How to better measure hedonic residential property price indexes. International Monetary Fund Working Papers, 16(213).

Sims, D. P. (2007). Out of control: What can we learn from the end of Massachusetts rent control? Journal of Urban Economics, 61(1):129-151.

Smirnov, D. S. (2009). Промышленный пояс: южные окраины Санкт-Петербурга в конце ХIX начале XX века (Industrial belt: Southern suburbs of Saint-Petersburg in the late 19th - early 20th centuries). Известия Российского государственного педагогического университета им. А.И. Герчена, 118:74-82.

Statisticheskoe otdelenie Petrogradskoy gorodskoy upravy (1916). Статистические данные, относящиеся $к$ городу Петрограду и Петроградскому городскому хозлйству (в диаграммах) (Statistical data on Petrograd and its communal services in diagrams). Петроград: Городская типография.

Strumilin, S. G. (1966). Очерки экономической истории России и CCCP (Essays on economic history of Russia and the USSR). Москва: Наука.

Suvorin, A. S. (1912). Весь Петербург на 1912 год: адресная и справочная книга г. С.-Петербурга (Whole Petersburg in 1912: An address and reference directory). СПб.: Издание А.С. Суворина.

Suvorin, A. S. (1913). Весь Петербург на 1913 год: адресная и справочная книга г. С.-Петербурга (Whole Petersburg in 1913: An address and reference directory). СПб.: Издание А.С. Суворина.

Thompson, F. M. L. (1988). The Rise of Respective Society: A Social History of Victorian Britain 1830-1900. Fontana Press, London, UK.

Wallace, N. E. and Meese, R. A. (1997). The construction of residential housing price indices: A comparison of repeat-sales, hedonic-regression, and hybrid approaches. The Journal of Real Estate Finance and Economics, 14(1/2):51-73. 
Waltl, S. R. (2016a). A hedonic house price index in continuous time. International Journal of Housing Markets and Analysis, 9(4):648-670.

Waltl, S. R. (2016b). Variation across price segments and locations: A comprehensive quantile regression analysis of the Sydney housing market. Real Estate Economics, doi:10.1111/1540-6229.12177.

Willis, J. W. (1950). Short history of rent control laws. Cornell Law Review, 36(1):54-94.

Wood, S. N. (2006). Generalized Additive Models: An Introduction with R. Chapman and Hall / CRC, Boca Raton, Florida.

Wood, S. N., Bravington, M. V., and Hedley, S. L. (2008). Soap film smoothing. Journal of the Royal Statistical Society: Series B (Statistical Methodology), 70(5):931-955. 


\section{Appendix A. The Housing Market in St. Petersburg at the Turn of the Century}

This section characterizes the St. Petersburg housing market prior to the October 1917 Revolution and presents supplemental demographic information. We further describe the significant political events that shook the Russian Empire in the early 1900s and finally led to its collapse. The background information presented here facilitates a better understanding of the historic setting and our empirical results.

Appendix A.1. Characteristics of the Housing Market and Demographic Information

Appendix A.1.1. Geographic Area and Administrative Division

Prior to the October 1917 Revolution, the city covered an area of 90.3 square kilometers (today: 1,403 square kilometers). The territory of the city was divided into twelve police districts (politseyskaya chast), each consisting of two to four sub-districts (politseyskiy uchastok). In 1869, there were 38 subdistricts. By 1910, the number increased to 42 due to the division of Alexandro-Nevskaya, Narvskaya, and Vasilyevskaya districts into several sub-districts as well as through the inclusion of the Novoderevenskiy sub-district into the city boundaries. Informally, the city also included six further sub-districts: Alexandrovskiy, Bol'shaya and Malaya Okhta, Lesnoy, Palyustrovskiy, Petergofskiy, and Shlissel'burgskiy. Formally, as these were located in Sankt-Peterburgskaya governorate, these were outside of the administrative borders of St. Petersburg. However, economically they belonged to the city. ${ }^{27}$

\section{Appendix A.1.2. Population and Demographics}

During the period under consideration, 1880-1917, St. Petersburg was the capital of the Russian Empire and its largest city. Within the contemporary administrative boundaries, its population was 667,207 in 1869, increasing to 1,597,013 in 1910, according to the population censuses that were conducted in St. Petersburg on a roughly decennial basis. In its modern boundaries, the city had a population of 843,100 in 1880, then 1,881,300 in 1910 and 2,300,000 in 1917 (Eliseeva and Gribova, 2003, p. 16-17).

In 1910, St. Petersburg had an average population density of over 15,000 persons per square kilometer. ${ }^{28}$ Within the city, the density varied widely: between 1,013 in the sub-district Vyborgskaya 3 and 95,880 in the sub-district Spasskaya 3 (1910). Admiralteyskaya district had a relatively low population density, since the aristocracy's palaces (including the imperial Winter Palace) and government buildings are predominately located there.

Prior to the October 1917 Revolution, St. Petersburg was a predominantly male city due to its function as an imperial capital: at that time, civil servants and military personnel were always men. The share of women in St. Petersburg's population gradually grew from $43.4 \%$ in 1869 to $47.8 \%$ in 1910 .

\footnotetext{
${ }^{27}$ Unfortunately, for most of them the exact boundaries are unknown - no map from this era shows the borders. Using a raster image of the administrative map of St. Petersburg in 1902 and the program QGIS we created a historical shapefile of the city districts and sub-districts including Bol'shaya and Malaya Okhta, which we use to construct the maps presented in this article.

${ }^{28}$ For comparison, in 1911, the population density in Inner London was 38,352 persons per square kilometer; see http: //www.demographia.com/dm-lon31.htm.
} 
Figure A.9: Population Density (Persons per Hectare) by Sub-Districts, 1910

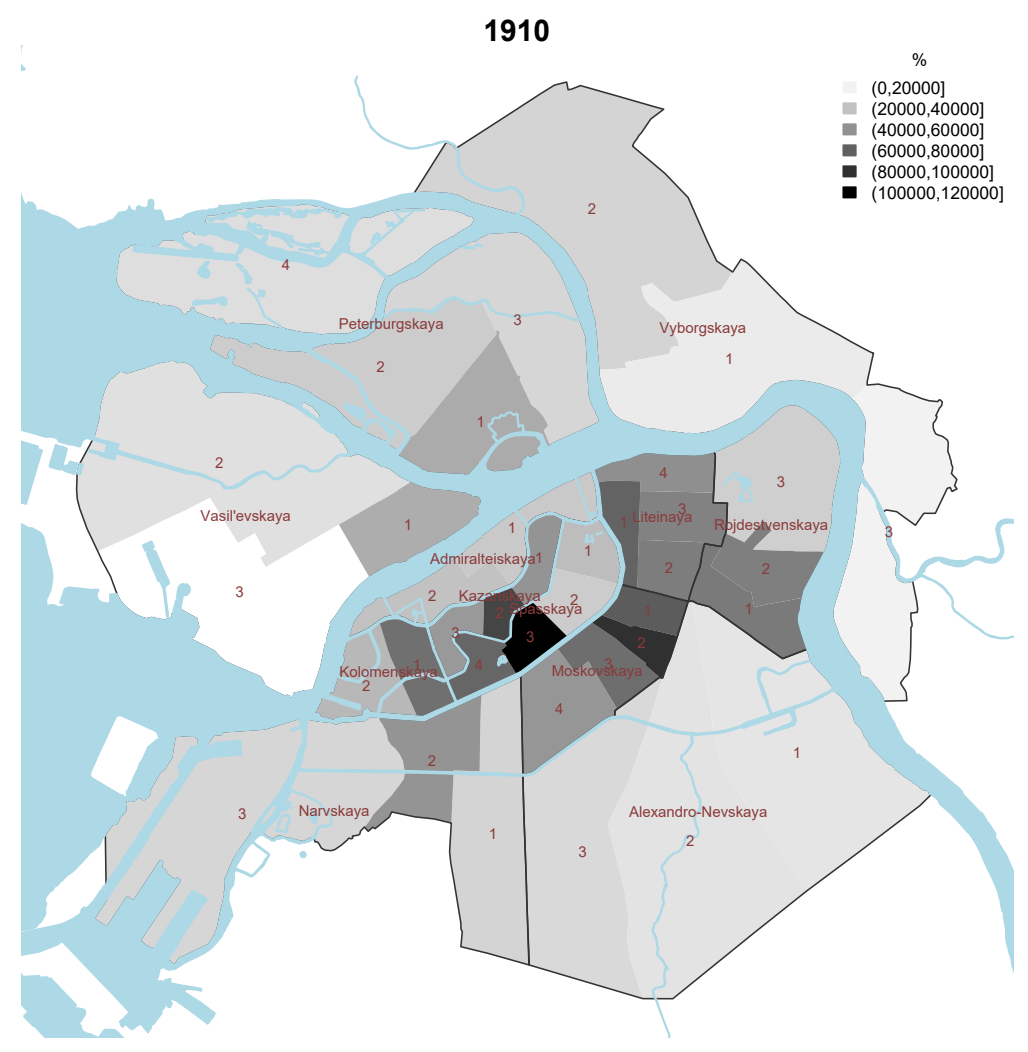

Figure A.10 depicts the proportion of women per sub-district, which was very heterogeneous. In 1910, the share of women ranged between $38.4 \%$ in the Spasskaya 2 sub-district and $57.2 \%$ in the Kazanskaya 1 sub-district. The highest concentration of men is observed in those sub-districts that were dominated by either ministerial offices, or companies and factories. Thus, the outbreak of the war, which led to a mass mobilization of men, could (and in fact did) affect the demand for housing in different areas of the city to different degrees.

During the period under study, St. Petersburg was not only an administrative and a military center of Russia but also an important industrial city. Hence, it had a large working class population. Most of the workers, especially singles, rented the dwellings in the lower segment of the housing market. Others lived in barracks provided by their employers. Unfortunately, the distribution of worker population by these types of accommodation is unknown. Figure A.11 shows the share of workers in the population in 1910. Two districts in the south (Alexandro-Nevskaya and Narvskaya) and one in the north (Vyborgskaya) had the highest shares of workers. The major manufacturing sites were located in these districts (see also Smirnov, 2009). The proportion of workers per district correlates with district-specific crowding rates shown in Figure A.13. 


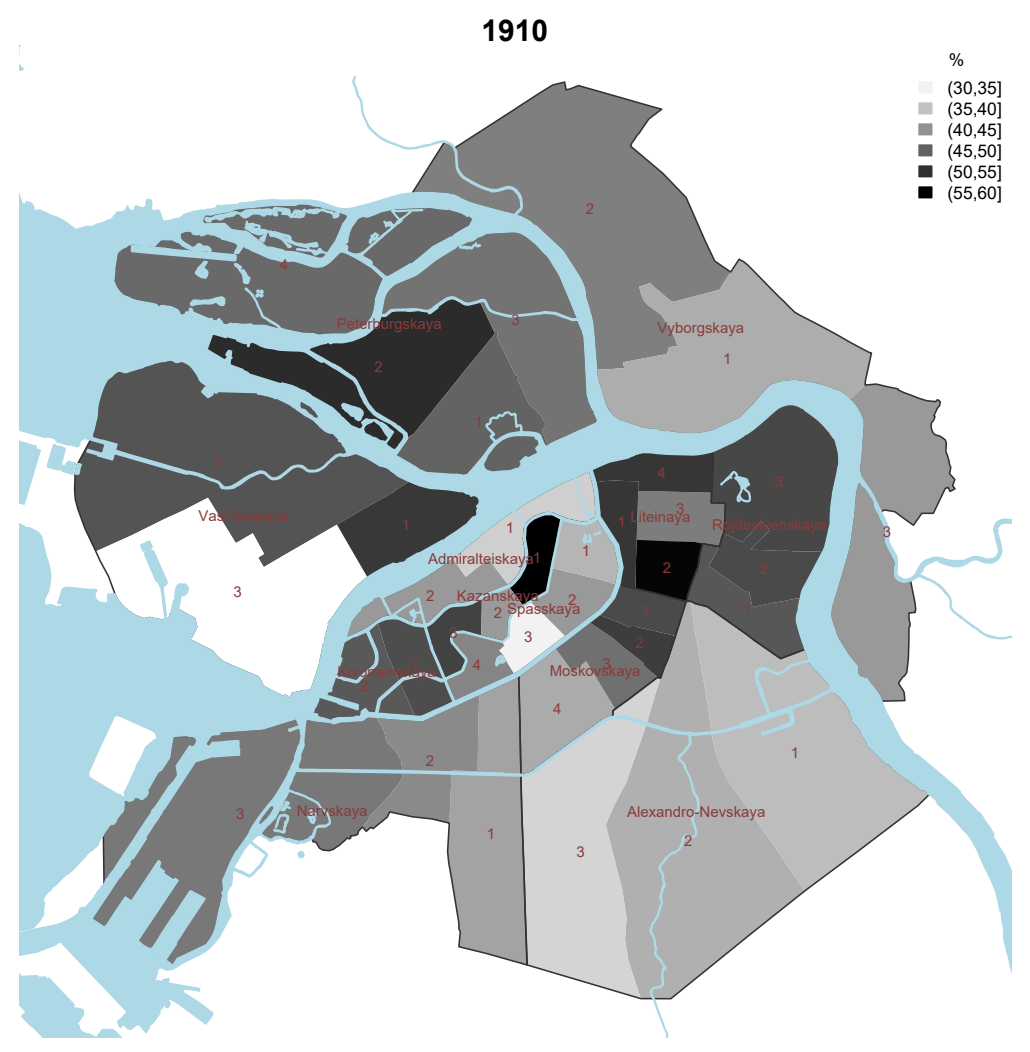

Appendix A.1.3. Literacy

Prior to World War I, the literacy rate was relatively low in Russia. According to the 1897 population census, only $49 \%$ of the urban population in the European part of the Russian Empire were able to read and write. In St. Petersburg, the literacy rate was substantially higher and rapidly growing over time: from $60.5 \%$ (of all persons aged six years or older) in 1869 to $76.6 \%$ in 1910 (see Table A.4). The literacy rate was substantially higher among men than among women with a difference of more than 20 percentage points. For example in 1910, 87.9\% of all male citizens in St. Petersburg could read and write, whereas only $64.7 \%$ of all females citizens possessed these skills.

\section{Appendix A.1.4. Homeownership}

In the late 19th and early 20th century, the vast majority of the population in St. Peterburg were renters. The population and housing censuses conducted in St. Petersburg document very low homeownership rates: $3.6 \%$ in $1900 .^{29}$ Two main factors led to such low homeownership rates: first, there was a large number of multi-family and multi-story rental houses (dokhodnye doma) in the city. ${ }^{30}$ Typically,

\footnotetext{
${ }^{29}$ The rate is computed as the proportion of the owner-occupied dwellings in the total number of dwellings.

${ }^{30}$ In 1910, 55\% of all residential buildings in St. Petersburg were made of stone, while in the rest of the Russian Empire (except Finland) the share was only 23\% (Central'nyi Statisticheskii Komitet MVD, 1914). Given that small single-family houses were usually built of wood, we conclude that more than half of the population lived in multi-family residential houses
} 
Figure A.11: Share of Workers in St. Petersburg by Sub-Districts, 1910

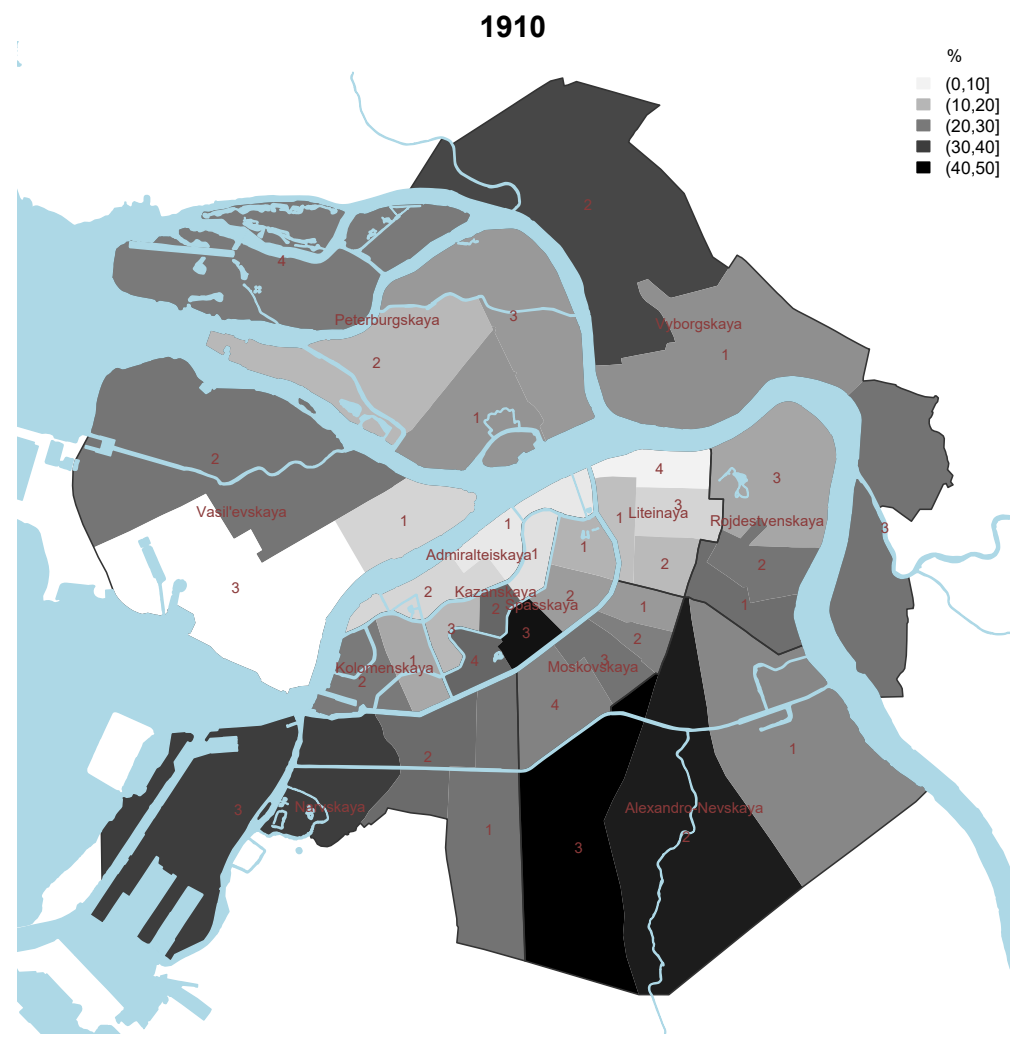

they had four floors, each with three to four apartments. One apartment could be occupied by the owner of the house and his family. Thus, as a rule, only one apartment out of 12-16 was owner-occupied. Second, the condominium (also known as horizontal or strata title) property type did yet not exist. Except for a tiny market of housing cooperatives, one could only own the whole house, but not a single apartment. Given the large size of the houses located in the central districts of the city, only very few could afford to own an entire property. Thus, most city dwellers were forced to rent an apartment or room, and, if they were very poor, even a corner or bed only.

Such low homeownership rates were common in these times. In the large German urban settlements, the share of owner-occupied dwellings in the overall housing stock ranged between $3 \%$ and $10 \%$ (Brander 1984, p. 81). Even in Britain - a country characterized by a large share of single-family houses, which strongly correlates with the homeownership rate (Kohl, 2017) - working and middle-class families were typically renting their home from private landlords. In the UK, only approximately $10 \%$ of the total housing stock were owner-occupied at the eve of World War I (Thompson, 1988).

in St. Petersburg. These numbers are based on data from Central'nyi Statisticheskiy Komitet MVD (1915). 
Table A.4: Literacy Rates in St. Petersburg, 1869-1910, \%

\begin{tabular}{l|ccccccc}
\hline \hline \multirow{2}{*}{ Year } & \multicolumn{3}{|c}{$\geq 6$ years old } & & \multicolumn{3}{c}{$\geq 16$ years old } \\
& male & female & all & & male & female & all \\
\cline { 2 - 4 } \cline { 7 - 8 } 1869 & 67.2 & 51.6 & 60.5 & & & & \\
1881 & 71.8 & 55.1 & 59.5 & & & & \\
1890 & 74.4 & 53.6 & 64.8 & & 74.0 & 50.8 & 63.3 \\
1900 & 79.7 & 59.3 & 70.5 & & 80.0 & 57.1 & 69.7 \\
1910 & 86.3 & 65.8 & 76.6 & & 87.9 & 64.7 & \\
\hline \hline
\end{tabular}

Notes: The table reports literacy rates in \% for St. Petersburg. Sources: Rashin (1956); own calculations based on Central'nyi Statistichekiy Komitet MVD (1872, 1891, 1903), and Statisticheskoe otdelenie Petrogradskoy gorodskoy upravy (1916).

\section{Appendix A.1.5. Vacancy rate}

The vacancy rate characterizes the tenseness of the housing market: a low vacancy rate points to a shortage of housing, while high vacancy rates indicate an excessive supply of housing. In 1869, 1890, and 1900 , the census reports numbers of vacant dwellings. The vacancy rate, computed as the share of empty dwellings in the total number of dwellings, equals $5.5 \%$ in $1869,6.2 \%$ in 1890 , and $3.9 \%$ in 1900 . These rates are comparable to, for example, Berlin (1890-1900), where vacancy rates were on average $3.6 \%$, and fluctuated between $1.0 \%$ and $6.2 \%$ (see Kholodilin, 2016).

Across St. Petersburg's sub-districts, vacancy rates varied substantially (see Figure A.12). Many vacancies were observed in the sub-district Petrogradskaya $4(32.5 \%)$, which used to be a place where well-off city inhabitants spent their summer vacations. The census was typically conducted in December, when many of the summer residences were empty.

\section{Appendix A.1.6. Residential Mobility}

At that time, the residential mobility was very high. In the early 1910 s, roughly $30 \%$ of middle and upper class members changed their address within a year. In other words, the average tenure duration was about 3.5 years. While the residential mobility was rather stable between 1912 and 1915, it dropped significantly thereafter (see Table 3 for detailed results and section 4 for methodological details).

For lower-income persons, residential mobility was likely even higher: first, due to the high instability of earnings and the absence of any protection for tenants from being evicted by landlords prior to November 1915. Second, residential mobility rates are calculated from directories that include (almost) all of the less mobile owner-occupiers and, thus, constitute a lower bound.

For comparison, between 1891 and 1914, the residential mobility in central quarters of Lyon fluctuated around 10\% (see Bonneval and Robert, 2012, p. 44). Today, residential mobility is lower: for example, the average tenure duration was 6.8 years in Denmark in 1999 (see Munch and Svarer, 2002, p. 550) and 11.2 years in Hamburg in 2015 (Mannigel and Jackisch, 2016, p. 1). Unfortunately, we could not find contemporaneous data for St. Petersburg. 


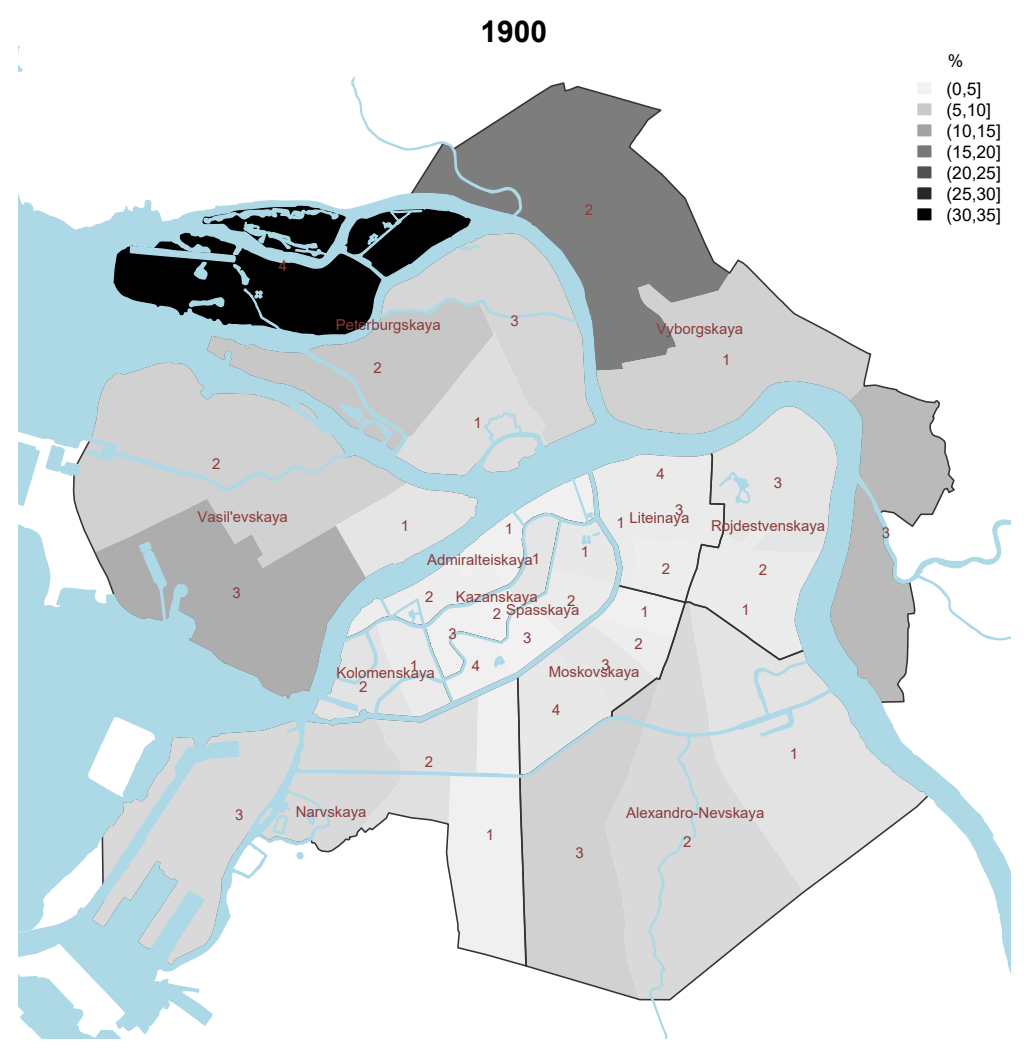

Appendix A.1.7. Crowding

Residential density is an important characteristic of a housing market. It can be calculated at the house, dwelling, or room levels, and reflects both living conditions (e.g., too high residential density, known as over-crowding, is associated with poor sanitary conditions and high incidence of epidemics of infectious diseases) and the architectural landscape (e.g., high-rise multi-family houses versus detached single-family houses).

Figure A.13 depicts the crowding rate measured as the average number of persons per room in a residential building based on the housing censuses. In 1910, it ranged between 1.4 and 4.1 across subdistricts. It was particularly high in Alexandro-Nevskaya and Narvskaya districts, where manufacturing factories were concentrated. For the whole city, the crowding rate was on average 2.4 persons per room. Is that a sign of overcrowding? In the early 20th century, different countries used different definitions of over-crowding: in England, the threshold was two persons per room, while in Germany it was five persons per room (see Eberstadt, 1920, p. 203). Given that we report only averages, a relatively large proportion of dwellings were over-crowded even when measured against the more liberal German standards.

Both in national and international terms, the overall residential density in St. Petersburg was high. For instance, in Moscow in 1902, the average number of persons per room was 2.1, varying between 1.7 in the central part of the city and 2.6 in the periphery (Sheremetevskiy, 1916, p. 895). In London, the 
average crowding rate equaled 1.1 persons per room in 1911 (Eberstadt, 1920, p. 578), whereas in Vienna it was 1.3 to 1.4 persons per room in 1900 (depending on the definition of the administrative borders of the city, see Feldbauer, 1979, p. 323). The high rate in St. Petersburg can be explained by widespread subletting practices. Often, poor households sublet parts of the dwelling they occupied in order to earn additional income.

An additional crowding indicator from official statistics ${ }^{31}$ is the total living surface a person occupies in $m^{2}$. In 1910, the average indicator for the city excluding outskirts was $8.8 \mathrm{~m}^{2}$, varying from only $4.7 \mathrm{~m}^{2}$ in workers-dominated subdistrict Alexandro-Nevskiy 4 to $13.4 \mathrm{~m}^{2}$ in the aristocratic subdistrict Kazanskiy 1. By 1915, the average number decreased to $7.6 \mathrm{~m}^{2}$ (and ranged between $4.6 \mathrm{~m}^{2}$ in subdistrict Vyborgskiy 1 and $16.4 \mathrm{~m}^{2}$ in subdistrict Spasskiy 2). By 1918, the housing area per person substantially increased to $12.7 \mathrm{~m}^{2}$ due to people leaving a "hungry and cold city." Unfortunately, we cannot identify whether this process started already in 1917 or only in 1918.

St. Petersburg was also characterized by the dominance of large houses: in 1900, on average 36.1 persons lived in one house. On this measure, St. Petersburg ranks in the European midfield: in London, one house was occupied by on average 7.9 persons in 1901 (Eberstadt, 1920, p. 575), in Hamburg by 35.6 and in Berlin by 77.0 both in 1900 (Eberstadt, 1920, p. 167).

\section{Appendix A.1.8. Housing Construction}

Over the period under investigation, housing construction in St. Petersburg fluctuated widely. Figure A.14 shows the total number of houses newly built or rebuilt between 1883 and 1916 as well as the number of applications for building permits submitted by investors to the city government between 1902 and 1917. The information we have is rather rough, as we cannot distinguish between single- and multi-family houses. No information on the number of completed dwellings is available for this period. ${ }^{32}$ At the turn of the century, the number of constructed and reconstructed houses attained its maximum. The next, albeit much lower, peak was in 1913-1914, according to the number of applications for building permits. During World War I, construction activity contracted a lot, falling almost to zero in 1917, thus exacerbating the housing shortage.

Appendix A.1.9. Rents

Relatively little is known about the cost of renting in St. Petersburg and even less about its evolution. Next to the index we construct in this article, the only other source we are aware of are the housing

\footnotetext{
${ }^{31}$ We found this indicator in the supplemental materials accompanying the 1910 housing and population census in St. Petersburg, which are kept in the Tsentral'nyi gosudarstvennyi istoricheskiy arkhiv Sankt-Peterburga, F. 513, Op. 171, D. 33 , L. 27.

${ }^{32}$ Data on the housing construction are dispersed across various sources. In principle, the city government (Gorodskaya uprava) was responsible for collecting and publishing this information. However, it was rarely published in the St. Petersburg's statistical yearbooks, which is why we mainly rely on the address directories Ves' Peterburg and archival records of the Department of city government for private construction (Otdel chastnovladel'cheskogo stroitel'stva). In addition, the number of applications for building permits (khodataistva o postroykakh) is used as a proxy for housing construction. The data are taken from the weekly architectural magazine "Zodchiy," where almost every issue contained a list of applications for building permits submitted in the preceding weeks.
} 
Figure A.13: Crowding Rates by Sub-Districts, 1910

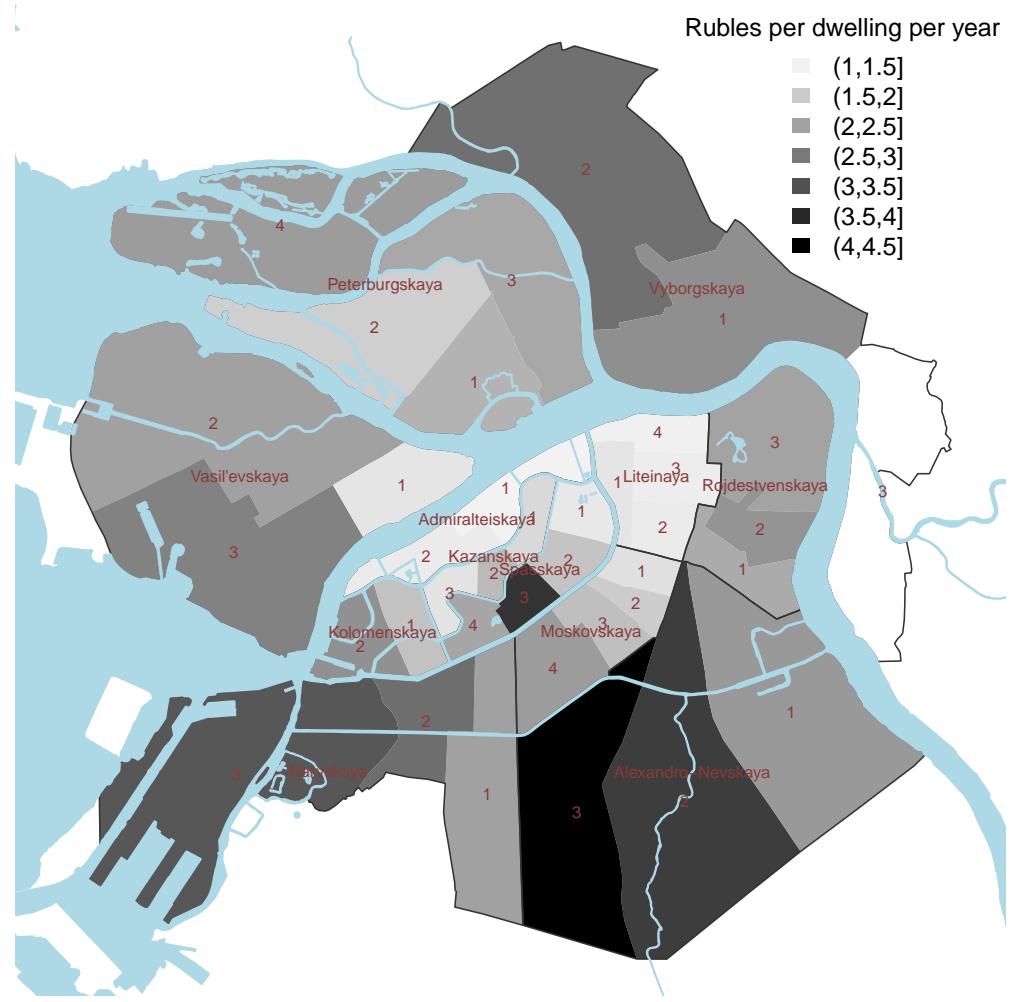


Figure A.14: Housing Construction, 1883-1916

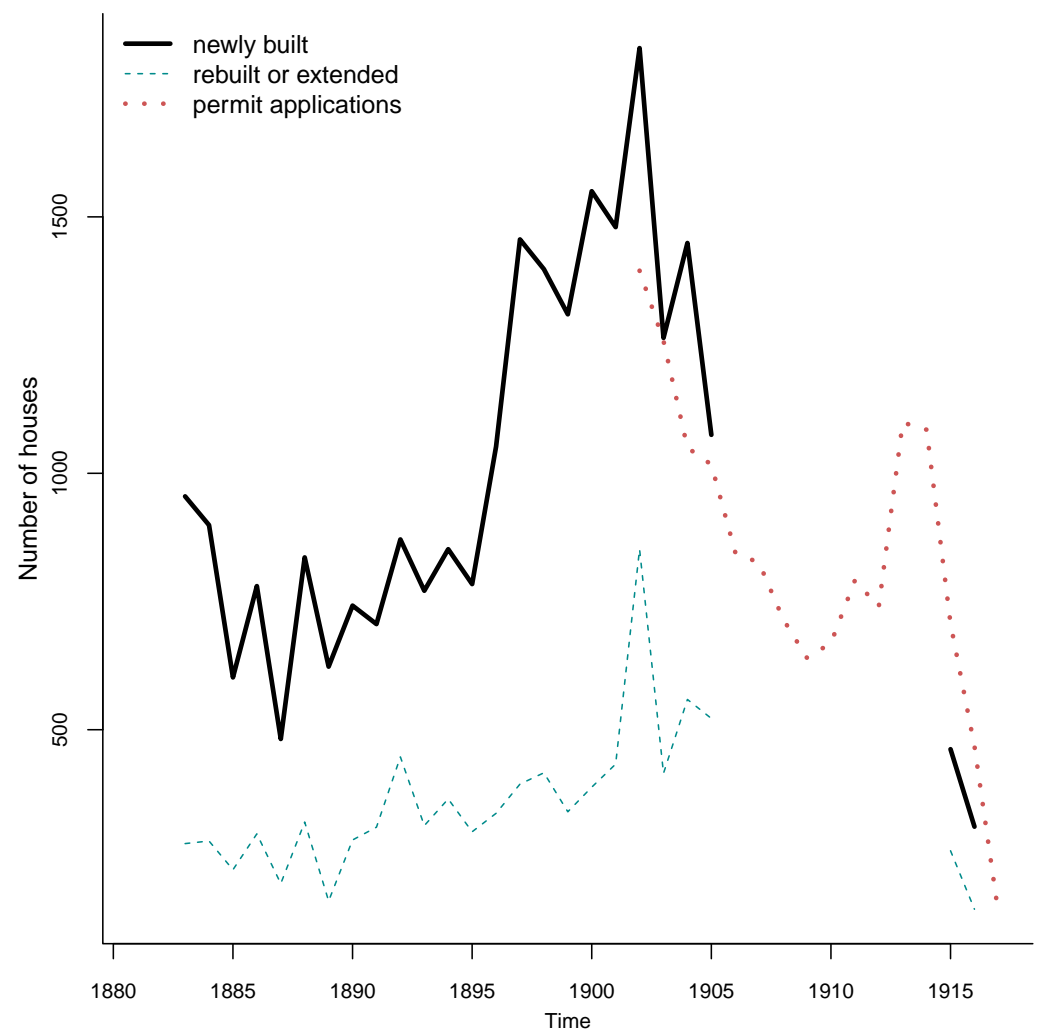

Sources: Ves Peterburg, Gorodskaya uprava, magazine "Zodchiy", and authors' own calculations. 
censuses that were conducted in St. Petersburg since 1869 on a roughly decennial basis, which are also the source data of the index documented in Strumilin (1966).

Figure A.15 shows average annual housing rents in St. Petersburg by sub-district between 1869 and 1900 reported in the census. The highest rents are observed in the central districts, along the river Neva. The relatively high rents in the sub-district Peterburgskiy 4 (from 1881 onward) are due to its recreational character: this sub-district comprises several islands covered by parks, which the well-off city inhabitants enjoyed during their vacations they used to spent in their summer residences.

It is worth noting that, over time, the rents increased in a growing number of sub-districts following the expansion of the city. A remarkable example is the district Perterburgskaya, where in the 1890s, low-rise wooden houses were replaced with five to six stories tall, large residential buildings.

The spatial distribution of rents is very similar to the distribution of land prices in 1897 (Limonov, 1997, Figure 25). Limonov relies on data from the statistical yearbooks and the mortgage bank Kreditnoe obshchestvo.

\section{Appendix A.2. Historic Events}

The late 19 th century and early 20 th century were shaken by important historic events (see Table A.5): within less than twenty years, Russia experienced the Russian-Japanese war (1904-1905) followed by the first Russian revolution (1905-1907), World War I (1914-1918), as well as the second and the third Russian Revolutions (both in 1917).

Table A.5: Major Events

\begin{tabular}{l|cc}
\hline \hline Event & \multicolumn{2}{c}{ Date } \\
& Gregorian calendar & Julian calendar \\
\hline Russian-Japanese War & Feb. 9, 1904- Sep. 5, 1905 & Jan. 27, 1904- Aug. 23, 1905 \\
First Russian Revolution & Jan. 22, 1905- June 16, 1907 & Jan. 9, 1905 - June 3, 1907 \\
World War I & July 28, 1914- Nov. 11, 1918 & July 15, 1914- Oct. 29, 1918 \\
Introduction of rent control in Petrograd & Dec. 9, 1915 & Nov. 26, 1915 \\
Introduction of all-Russia rent control & Sep. 9, 1916 & Aug. 27, 1916 \\
February Revolution & Mar. 8, 1917 & Feb. 23, 1917 \\
October Revolution & Nov. 7, 1917 & Oct. 25, 1917 \\
\hline \hline
\end{tabular}

Notes: The table reports the exact dates of major events potentially affecting the housing rents in St. Petersburg. Russia used the Julian calendar before introducing the today's internationally used Gregorian calendar on January 26, 1918 .

These events also implied housing supply and demand shocks. The wars are typically associated with an initial decline of demand for housing due to mobilization of male citizens. Later, the demand increases again due to the inflow of workers employed by the weapon factories and of refugees fleeing from the regions devastated by the war. At the same time, supply decreases because of the shortage of capital, building materials, and construction workers. As a result, the housing stock cannot be maintained and no new construction is undertaken. 
Figure A.15: Average Annual Rents by Sub-Districts, 1869-1910

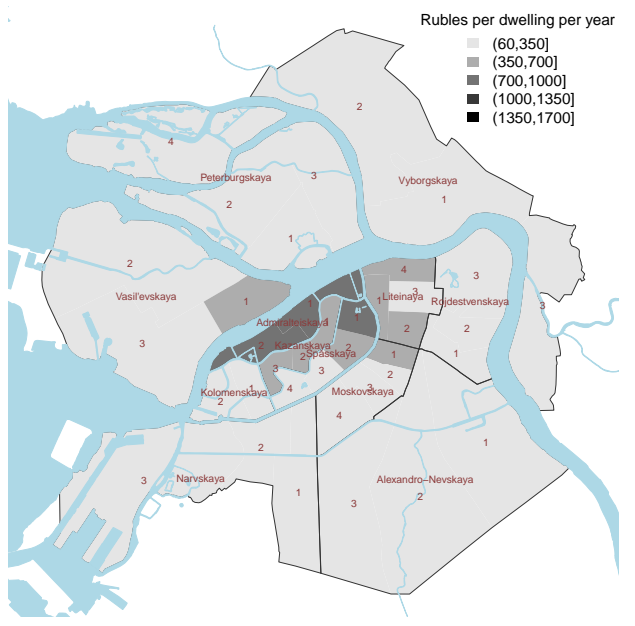

(a) 1869

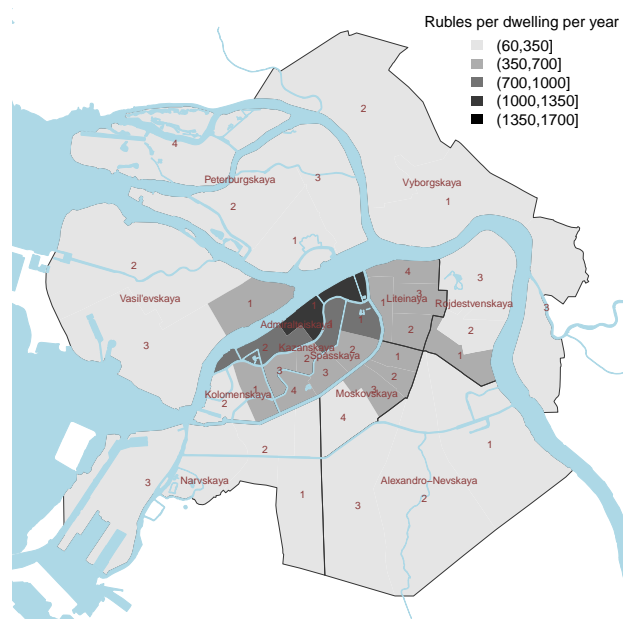

(c) 1890

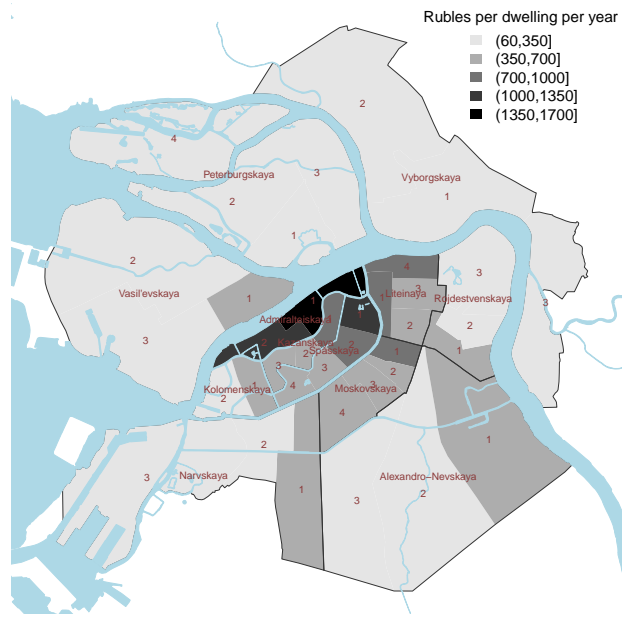

(b) 1881

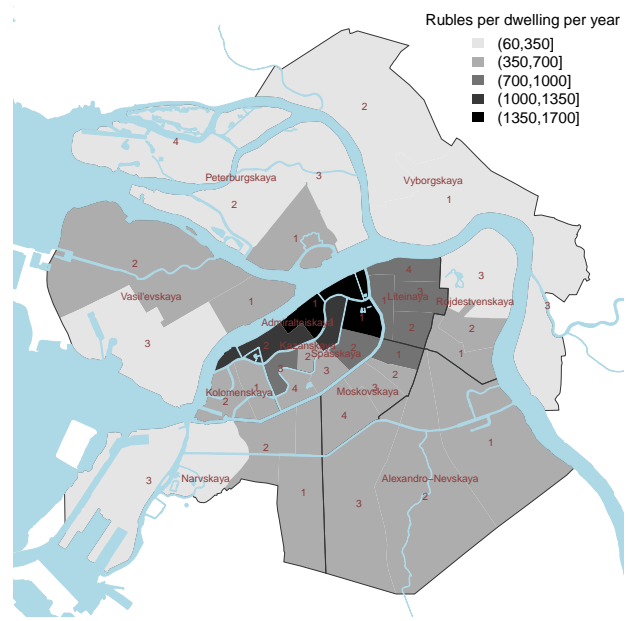

(d) 1900

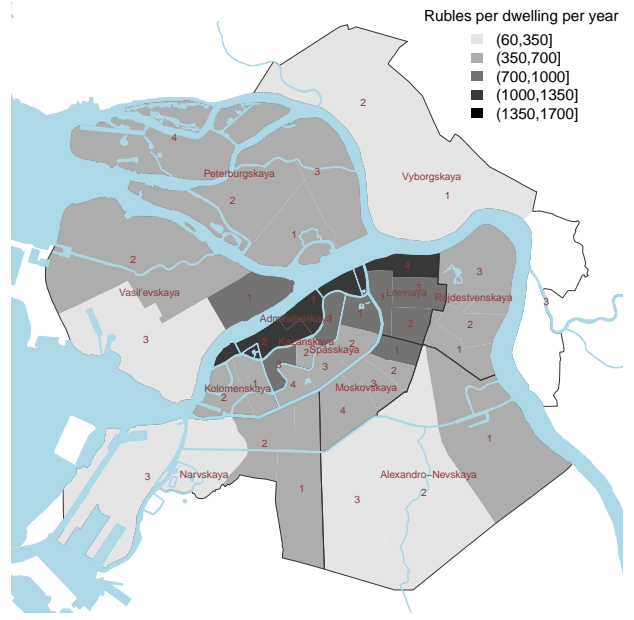

(e) 1910 


\section{Appendix B. Rent Price Index}

\section{Appendix B.1. Index Construction Techniques}

Dwellings are extremely heterogeneous goods: no two dwellings are the same as they differ in their structural (e.g., number of rooms, furnished or not furnished, etc.) and their locational characteristics. Thus, when constructing indices it is important to take these differences in characteristics into account in order to compare like with like.

The housing price index literature distinguishes three main approaches to account for differences in the mix of characteristics, which is usually referred to as "quality-adjustment" (see Hill, 2013; de Haan and Diewert, 2013): stratification, repeat-sales, and hedonic approaches.

Stratification methods are the easiest form of quality-adjustment: dwellings with similar characteristics are pooled and average (mean or median) prices or rents are computed for each of these "homogenized" strata. An overall index is obtained by aggregating averages over all strata in a suitable way.

The repeat-sales methodology (Bailey et al., 1963; Case and Shiller, 1989) restricts the analysis to dwellings that appeared at least twice on the market and only rely on price pairs of the same dwelling. The major benefit is that only prices/rents of comparable dwellings are considered (i.e., identical dwellings, except for age/depreciation and changes due to renovations). Dwellings that appear on the market for the first time are, per construction, excluded. Our data do not include a unique identifier of rental units, which would enable an unambiguous identification of repeated rentals. Thus, we match observations based on the geo-coded address and all available structural characteristics, and use the resulting pairs to construct a repeat-rent index as benchmark. See Appendix B.3 for details.

Hedonic approaches (for an overview see Silver, 2016) build on the assumption that the price or rent of a dwelling is determined by shadow prices associated with the dwelling's characteristics. For instance, there is a shadow price for a bathroom, an extra bedroom, and so on. Locational characteristics are also associated with (positive or negative) shadow prices as location proxies every aspect of a neighborhood affecting the value of the property, such as the distance to certain amenities or disamenities, noise, pollution, access to public transportation, and so on.

Regarding the modelling of locational attributes, there are two main strategies: either distances to amenities and neighborhood characteristics are explicitly modelled in the hedonic equation, or the attractiveness of a location is implicitly modelled. An implicit modelling strategy can rely on geographical dummy variables, geographic splines, or on modelling spatial autocorrelation via a spatial-lag matrix.

An explicit modelling strategy allows one to better understand the importance of certain characteristics for prices and rents. The implicit strategy assumes that locational characteristics are shared by dwellings within a short distance and, thus, model an overall locational price that can be interpreted as the general attractiveness of a neighborhood. The implicit approach circumvents the problem that the number of potentially important locational characteristics is endless and that functional forms are unknown. 
Here, we are interested in constructing an index. Hence, it is most important that the overall influence of location is modelled as accurately as possible and it is less relevant to understand the influence of certain locational characteristics. Thus, we apply an implicit locational modelling approach.

Hedonic approaches are most suitable for the historic data we collected for St. Petersburg. We know the exact location and have ample information on dwelling characteristics.

There are two major ways to construct hedonic indices: first, time-dummy methods pool observations from an extended period of time and include, next to dwelling characteristics, time-dummy variables indicating the time of transaction/advertisement. The coefficients of the time-dummy variables are interpreted as pure price changes net of quality differences and used to construct the price/rent index. In this case, one can also think of characteristics as control variables that help to filter out price changes that are not affected by the heterogeneity of dwellings currently on the market.

Second, imputation methods estimate separate hedonic models for each time period and use these models to impute prices/rents for a set of dwellings. The average of these imputed prices is tracked over time by exploiting standard price index formulae such as a Paasche and Laspeyres index.

Compared to contemporaneous index construction problems, the number of observations per year is relatively low (see also Table 1). Thus, estimating separate models for each year as needed for imputation indices is not feasible. Consequently, we rely on an adjusted version of the hedonic time-dummy methodology.

A pure time-dummy index is not appropriate for contemporaneous price index measurement as each time new data become available, the entire model needs to be re-estimated and index numbers potentially change. ${ }^{33}$ We do not face this problem in our historic analysis as the time period we look at is fixed.

Due to the limited number of observations, estimating even very low-frequency indices yields unstable results (see Figure 2). However, increasing the time period is problematic as the index will fail to detect changes in the market within each period.

Therefore, we switch from discrete time-dummy methods to a continuous version of the latter as proposed by Waltl (2016a). She argues that such a continuous approach is particularly suitable when aiming for high-frequency indices and/or when the number of observations is too small to obtain stable estimates for time dummies representing a reasonably long time period. In addition, the continuous approach overcomes what Waltl (2016a) calls an averaging effect that is particularly influential in the case of long (such as annual) time periods.

Waltl (2016a) shows that the continuous version of the time-dummy method yields very stable results even in the case of strikingly small sample sizes. Randomly drawing only $10 \%$ of the observations from the overall sample led to the same general results as relying on all observations in her study of Sydney.

It is possible, ex post to smooth indices that are too wiggly by, e.g., calculating a moving average

\footnotetext{
${ }^{33}$ For practical index construction, a "rolling window" approach, where the period considered in the hedonic equation moves forward over time holding the entire period length constant is more appropriate as ex post revisions are limited.
} 
over index numbers obtained from time dummies. We believe that this is the wrong way: confidence in unrealistically wiggly time-dummy coefficients is limited and ex post averaging increases smoothness but not reliability.

Smoothing during the estimation process (as in the case of the continuous index), however, yields a stable and reliable estimate of the "time trend" (i.e., the quality-adjusted price trend). No prior structure on the timing and nature of price changes is imposed. In contrast, any discrete hedonic method including the time-dummy method - imposes such prior structure as index number can only change once per period. Paraphrasing the latter: we let "the data speak" and not the index compiler.

\section{Appendix B.2. A Time-Continuous Heconic Index}

A standard log-linear time-dummy index for rental prices is constructed by first estimating a hedonic equation

$$
\log r=X \beta+D \delta+\varepsilon
$$

where $r$ denotes a vector of monthly rents; $X$ is a matrix whose columns contain information on structural and locational characteristics of dwellings; $\beta$ is an unknown vector of associated shadow prices; $D$ is a matrix of time-dummy variables; $\delta$ is a vector containing "period prices"; and $\varepsilon$ is a vector of random errors.

The base period (usually the first period) is normalized to zero and, thus, the price index is computed by taking the exponent of the estimated period prices: ${ }^{34}$

$$
\left(1, \exp \left(\hat{\delta}_{1}\right), \ldots, \exp \left(\hat{\delta}_{T}\right)\right)^{\top}
$$

A continuous index ${ }^{35}$ is obtained by replacing the time-dummy variables by a smooth function of time $f(\cdot)$. The variable time is calculated by transforming the publishing date of the rent advertisement (day/month/year) into a continuous variable (respecting the differences in the numbers of days per month).

The hedonic model changes to

$$
\log r=X \beta+f(\text { time })+\varepsilon
$$

The result is an additive model (for a general introduction see Wood, 2006). Like Waltl (2016a), we rely on adaptive smoothing for the time effect. Adaptive smoothing is beneficial since this allows the speed of changes in rental prices to vary over time: the estimation process is very flexible and is able to capture

\footnotetext{
${ }^{34}$ The log-transformation of the price or rent transforms a normal model into a log-normal model and, thus, a simple back-transformation taking the exponential function yields a biased estimate for the mean. See also Kennedy (1981). We follow Waltl (2016a) and refrain from a bias correction, as the result is an unbiased estimator for the median, which is sufficient in this case.

${ }^{35}$ We follow the methodology described in Waltl (2016a). We summarize the main steps here and refer to the original article for more details.
} 
both times of rather stable prices and times of rapid price changes. For St. Petersburg, we observe slowly moving rental prices between roughly 1880 and 1910, and rather fast changes thereafter.

A price index is obtained by evaluating the back-transformed time effect at a narrowly-spaced sequence of points in time time $=$ time $_{1}, \ldots$, time $_{T^{*}}$ and normalizing it to, for instance, time $=$ time $_{1}$ :

$$
\left(1, \frac{\exp \left(f\left(t i m e_{2}\right)\right)}{\exp \left(f\left(t i m e_{1}\right)\right.}, \ldots, \frac{\exp \left(f\left(t i m e_{T^{*}}\right)\right)}{\exp \left(f\left(\text { time }_{1}\right)\right)}\right)^{\top}
$$

Location is the most important dwelling characteristic. As it is simultaneously a proxy for many effects, the precise modelling of location is of utmost importance.

Exact addresses can be geo-coded in order to obtain geographical coordinates. These coordinates can be used to estimate smooth price maps defined on longitudes and latitudes, thus capturing variation in the "price of location" in a very precise way. ${ }^{36}$

St. Petersburg, nicknamed "Venice of the North," is bisected by the river Neva, with many canals interwoven. Numerous bridges connect the different parts of the city (see left panel in Figure B.16). This particular topographic situation needs to be accounted for when modelling locational effects. We define an area within which we model a smooth two-dimensional function of locational shadow prices. The area is determined by the main waterways and the outermost bridges (as of 1902), and overlaps the location of the bulk of rental observations. We discard only a few observations far from the historic city borders. The area is shown in the right panel of Figure B.16. This modelling approach has the effect that the relevant distance between two points, like A and B in Figure B.16, is not the air-line distance (dotted line) but rather the shortest distance within the modelling boundaries (solid line). Given that the density of bridges is quite high in the very center of the city, considering the outermost bridges as boundaries is a good approximation of reality.

A smooth locational map is estimated within these boundaries relying on "soap-film smoothing," which is designed to smooth data over such complex domains (Wood et al., 2008).

From here on, let $X$ denote a matrix that exclusively contains information on structural characteristics. In addition to these structural characteristics and the smooth time effect, the hedonic model finally also includes a two-dimensional smooth function defined on longitudes and latitudes, $g$ (long, lat), modelling the shadow price of location:

$$
\log r=X \beta+f(\text { time })+g(\text { long, lat })+\varepsilon .
$$

Shadow prices may change over time. Whereas this is less important for structural characteristics, the shadow price associated with different locations is very likely to evolve due to changes in the access

\footnotetext{
${ }^{36}$ Hill and Scholz (2017) and Waltl (2016a,b) directly include such price maps into hedonic equations. McMillen (2014) uses kernel density methods to model locational variation in similar manner.
} 
Figure B.16: Location of Advertised Rental Units and Coverage of the Soap-Film Smoother
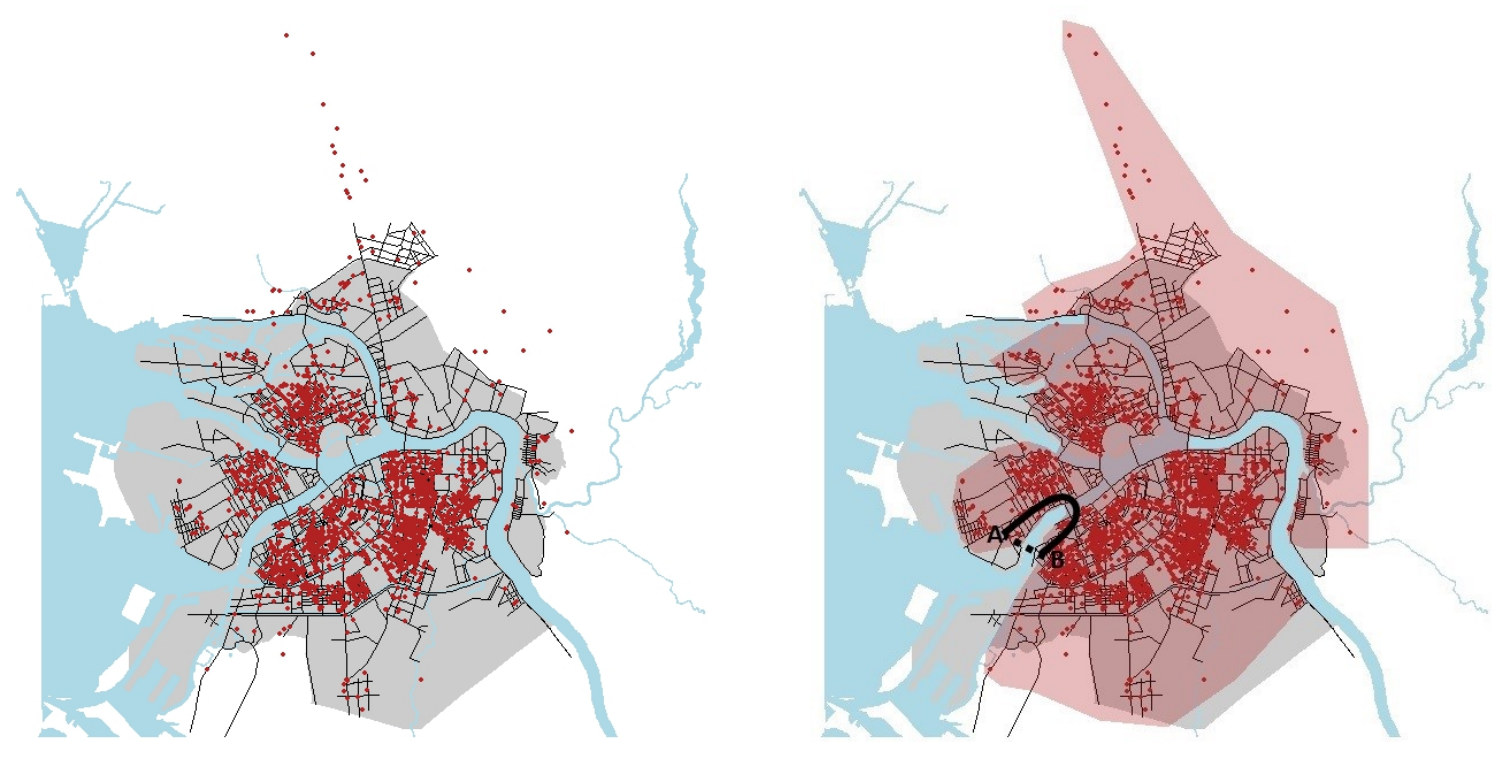

Notes: The figure shows the historic borders of St. Petersburg including the street net as of 1902. Additionally, the red dots indicate the location of all advertised rental units between 1880 and 1917. The gray shaded area indicates the boundaries for the soap-film smoother.

to local amenities including jobs and changes in demographics. We particularly expect such changes due to migration flows into and out of city over the period of observation. As proposed by Waltl (2016a) we do not keep $g($ long, lat) constant, but update it biennially.

\section{Appendix B.3. Multiple-Advertised Units}

\section{Appendix B.3.1. A Repeat-Rent Index}

As a benchmark for the hedonic indices, we construct a repeat-rent index. Figure 2 compares the resulting index to its hedonic counterparts.

Repeatedly sold dwellings produce quality-adjusted price pairs. The quality-adjustment is almost perfect: the dwellings differ only in their age and any potential unobserved renovations or remodeling. Dwellings that appear on the market only once are excluded. Nonetheless, there are also points of critique: the exclusion of dwellings showing up on the market for the first time, the larger influence of dwellings that sell multiple times (which are in contemporaneous housing markets found to be of systematically lower quality; see Wallace and Meese (1997) for a discussion of the so-called lemons bias) and the importance of unobserved renovations or remodeling.

Our source data do not include any information that would enable us to unambiguously identify repeated units. Thus, we use the detailed information on location and structural characteristics to identify rental units that were advertised multiple times. We match observations that are identical 
in their (geo-coded) address as well as all structural characteristics entering the hedonic model. Our conservative approach of using a long list of characteristics for matching minimizes (though not perfectly eliminates) the risk of potential mismatches, which would disturb the resulting index. It comes at the cost of likely missing some repeated advertisements.

We identify 3,682 unique rental units. Most appear only once in our sample (2,921 or 79.3\%). Another $496(13.5 \%)$ appear twice, $142(3.9 \%)$ three times, $53(1.4 \%)$ four times, and $70(1.9 \%)$ more than four times. The multiple observations yield 1,355 price pairs. For the annual repeat-rents index, we further disregard all repeats within the same year (576 pairs). We do not disregard these matches when analyzing the rent control policy.

A standard repeat-rent index emerges from aggregating individual price differences, which yields the repeat-sales regression model (see Bailey et al., 1963; Case and Shiller, 1989, for a derivation and further details)

$$
\log \left(\frac{r_{i, t}}{r_{i, s}}\right)=\sum_{t=0}^{T} \tau^{t} D_{i}^{t}+\varepsilon_{i}^{t},
$$

where $r_{i, t}$ and $r_{i, s}$ denote the rent of unit $i$ at times $t$ and $s$ respectively $(t>s)$ and $D_{i}^{t}$ denotes dummy vectors with entry 1 for the period of "re-rent," -1 for the period of the first advertisement, and 0 otherwise. Finally, $\varepsilon_{i}^{t}$ denotes an independent and identically distributed error term.

The estimated coefficients $\hat{\tau}^{t}$ are used to construct the index: the change in prices between the base period 1 and period $t$ is given as

$$
\exp \left(\hat{\tau}^{t}\right)
$$

As there are not enough observations to compute a stable quarterly index, we only compute annual index numbers. The results are shown together with the hedonic indices in Figure 2.

\section{Appendix B.3.2. Sample Selection}

The repeat-rent index finds very similar overall trends as the hedonic indices, although it is based on a sub-sample of our data. We analyze the characteristics of multiple-advertised units and compare them to unique observations to assess the existence of a potential selection bias.

We do not find evidence that repeated observations are systematically better or worse in their characteristics than rental units appearing just once in the sample. Repeated observations are slightly more often equipped with a bathroom, heating, and electricity. Further, they are slightly more likely to be furnished. On the other hand, repeated observations have on average a lower number of rooms and less often a balcony, and refer less often to an entire apartment. The differences are, however, rather small and often not significant (see Table B.6 and Figure B.17).

The individual differences in proportions of observations per district are insignificant at the 0.001 level for all but two districts. Hence, we conclude that the locational distribution of observations does not differ significantly between the two samples. 
Table B.6: Summary Statistics of Repeated vs. Unique Rental Units

\begin{tabular}{|c|c|c|c|c|c|c|}
\hline \multirow{2}{*}{ Number of rooms } & Mean & 1st Quartile & Median & 3rd Quartile & \multicolumn{2}{|c|}{$\Delta$} \\
\hline & & & & & & \\
\hline Repeated & 3.51 & 2.00 & 3.00 & 5.00 & & \\
\hline \multirow[t]{2}{*}{ Unique } & 3.91 & 3.00 & 4.00 & 5.00 & 0.000 & $* * *$ \\
\hline & \multicolumn{2}{|c|}{ Repeated } & \multicolumn{2}{|c|}{ Unique } & \multicolumn{2}{|l|}{$\Delta$} \\
\hline \multicolumn{7}{|l|}{ Share of } \\
\hline apartments vs. rooms & $85.8 \%$ & $14.2 \%$ & $89.4 \%$ & $10.6 \%$ & 0.008 & $* *$ \\
\hline bathroom vs. no bathroom & $78.8 \%$ & $21.2 \%$ & $76.1 \%$ & $23.9 \%$ & 0.118 & \\
\hline heating vs. no heating & $33.5 \%$ & $66.5 \%$ & $32.5 \%$ & $67.5 \%$ & 0.623 & \\
\hline electricity vs. no electricity & $94.2 \%$ & $5.8 \%$ & $91.5 \%$ & $8.5 \%$ & 0.021 & $*$ \\
\hline furnished vs. unfurnished & $100.0 \%$ & $0.0 \%$ & $99.6 \%$ & $0.4 \%$ & 0.182 & \\
\hline balcony vs. no balcony & $1.8 \%$ & $98.2 \%$ & $3.9 \%$ & $96.1 \%$ & 0.008 & $* *$ \\
\hline
\end{tabular}

Notes: The table reports summary statistics for structural characteristics of the advertised apartment or room. Unique refers to units that appear only once in the sample and repeated to observations appearing at least twice. Repeated observations are considered only once when describing the distribution of characteristics. The column $\Delta$ reports $p$-values. For binary variables, they refer to a two-sided test of equal proportions (Newcombe, 1998) and for the number rooms to a Wilcoxon rank-sum test. Significance codes: '***' if the $p$-value is lower than $0.001,{ }^{\prime} * *$ ' if the $p$-value is lower than ' 0.01 ', '*' if the $p$-value is lower than 0.05, ' ' if the $p$-value is lower than 0.1 and "' otherwise.

Figure B.17: Distribution of Rents in the Repeated and Unique Sample
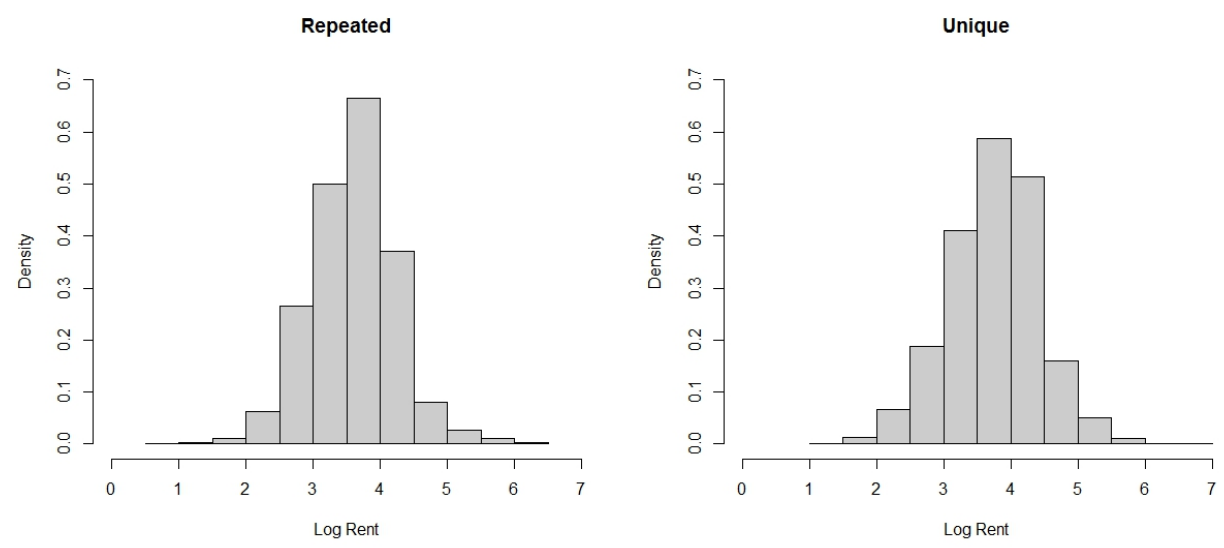

Notes: The figure shows densities of logged monthly rents for unique and repeated observations.

Additionally, we test differences in the annual distributions of advertised rents using a KolmogorovSmirnov (Wilcoxon rank-sum) test. Significant differences at the 0.001 level are found in two (three) out of 36 years only. At the 0.05-level differences are significant in eight (eight) out of 36 years. Hence, we conclude, that there are no economically important differences in advertised rents between repeated and unique observations. 